
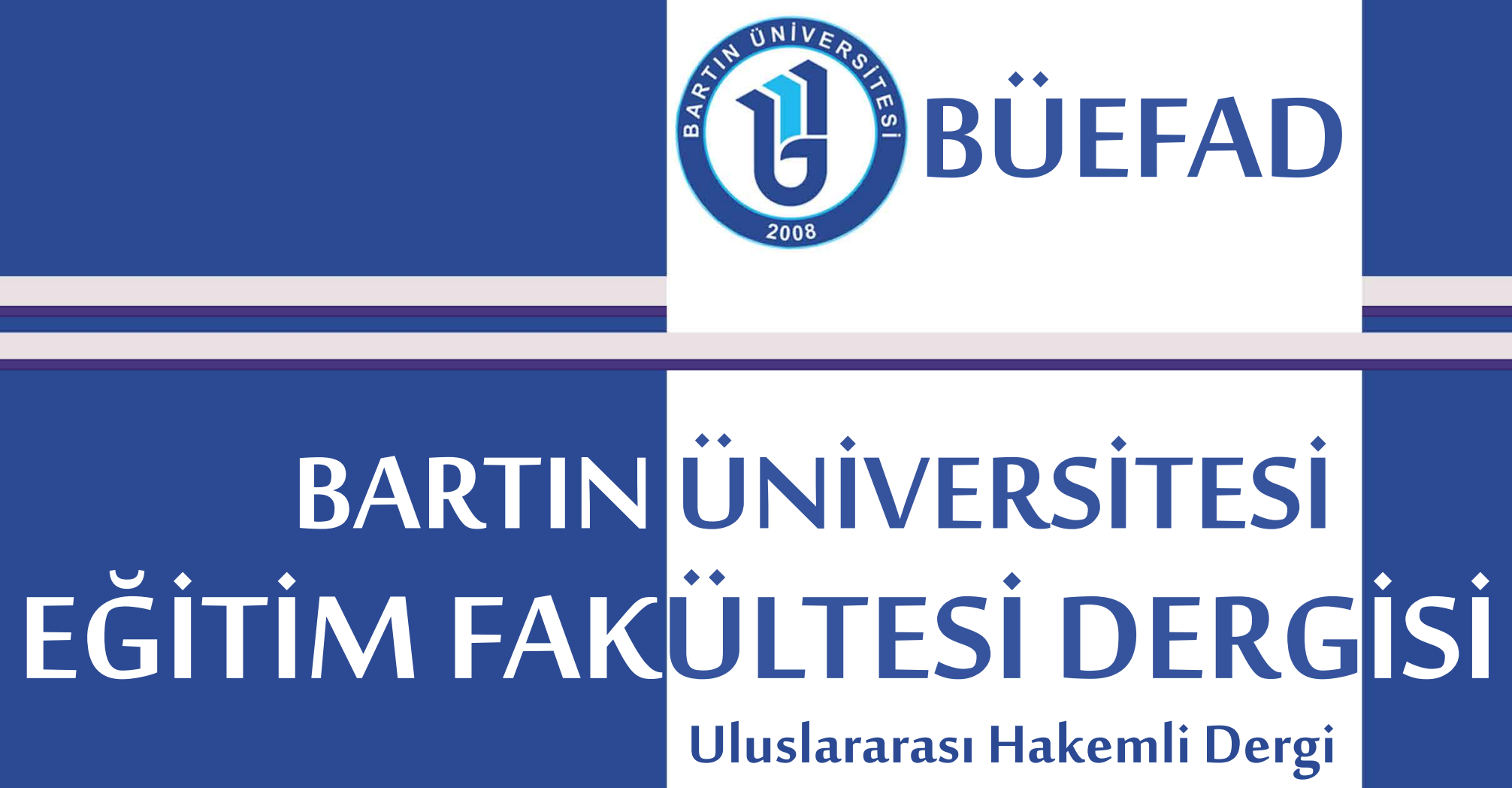

\section{- AYRI BASIM -}

Ars. Gör. Yunus ÖZYURT

Doç. Dr. Altay EREN

Fen Bilgisi Öğretmen Adaylarının Öğretmenlik Mesleğine ve Kopya Çekmeye Yönelik Tutumlarının Görünümü

\section{- SPECIAL EDITION -}

RA Yunus OZYURT

Assoc. Prof. Altay EREN

Profiles of Pre-Service Science Teachers' Attitudes towards the Teaching Profession and Cheating

ProcessForm

Objectives

Pre-Service

okuma vels echnology

Profession
Verbal Supervision Validity

Study Investigating Turkish

BARTINUNIVERSITY JOURNAL

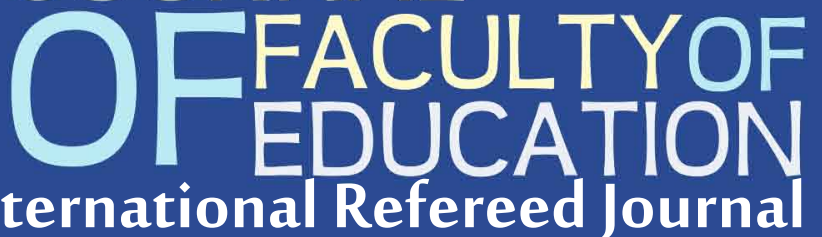

Cilt/Volume: $3 \quad$ Sayı/Issue: 1

Yaz/Summer 2014 ISSN 1308-7177
Teaching ${ }^{\text {Features }}$ University

Güvenirlik Geçerlilik

Çalışması Analysis Example
OzyeterlilikEleştirel

Attitudes Atyle $^{\text {Style }}$ 


\section{BARTIN ÜNIVERSİTesi EĞítim FAKüLTESI DERgisi}

BARTIN UNIVERSITY JOURNAL OF FACULTY OF EDUCATION

Cilt/ Volume: 3, Say1/Issue: 1, Yaz / Summer 2014

ISSN:1308-7177

\section{$\underline{\text { Sahibi }}$}

Bartın Üniversitesi Eğitim Fakültesi Adına Prof. Dr. Firdevs GÜNEŞ (Dekan)

Editör

Yrd. Doç. Dr. Sedat BALYEMEZ

\section{Alan Editörleri}

Doç. Dr. Çetin SEMERCi

Doç. Dr. Necati HIRÇA

Doç. Dr. Nuriye SEMERCi

Yrd. Doç. Dr. Ayşe Derya IŞIK

Yrd. Doç. Dr. Meliha KÖSE

Yrd. Doç. Dr. Neslihan USTA

Yrd. Doç. Dr. Sevan NART

Yrd. Doç. Dr. Sinem TARHAN

Yrd. Doç. Dr. Süreyya GENÇ

Yabancı Dil Sorumlusu

Yrd. Doç. Dr. Özge GÜN

\section{Yayıma Hazırlık}

Arş. Gör. Arzu ÇEVIK

Arş. Gör. Ömer KEMiksiz

\section{Sekretarya}

Arş. Gör. Hasan Basri KANSIZOĞLU

\section{Teknik Sorumlular}

Arş. Gör. Barış ÇUKURBAŞı

Arş. Gör. Fatma Gizem KARAOĞLAN YILMAZ

\section{İetişim}

Bartın Üniversitesi Eğitim Fakültesi

74100 BARTIN - TÜRKIYE

e-posta: buefad@bartin.edu.tr

Tel: +903782235219

Bartın Üniversitesi Eğitim Fakültesi Dergisi (BÜEFAD), yılda iki kez yayımlanan uluslararası hakemli bir dergidir. Yazıların sorumluluğu, yazarlarına aittir.
Owner

On Behalf of Bartin University Faculty of Education Prof. Firdevs GUNES (Dean)

$\underline{\text { Editor }}$

Asst. Prof. Sedat BALYEMEZ

Field Editors

Assoc. Prof. Cetin SEMERCI

Assoc. Prof. Necati HIRCA

Assoc. Prof. Nuriye SEMERCI

Asst. Prof. Ayse Derya ISIK

Asst. Prof. Meliha KOSE

Asst. Prof. Neslihan USTA

Asst. Prof. Sevan NART

Asst. Prof. Sinem TARHAN

Asst. Prof. Sureyya GENC

Foreign Language Specialist

Asst. Prof. Ozge GUN

Preparing for Publication

RA. Arzu CEVIK

RA. Omer KEMIKSIZ

Secretary

RA. Hasan Basri KANSIZOGLU

$\underline{\text { Technical Assistants }}$

RA. Baris CUKURBASI

RA. Fatma Gizem KARAOGLAN YILMAZ

Contact

Bartin University Faculty of Education 74100 BARTIN - TURKEY

e-mail: buefad@bartin.edu.tr

Tel: +90 3782235219

Bartin University Journal of Faculty of Education (BUJFED) is a international refereed journal that is published two times a year. The responsibility lies with the authors of papers. 


\section{DiZINLENME VE LISTELENME / INDEXING AND LISTING}

Bartın Üniversitesi Eğitim Fakültesi Dergisi, aşağıdaki indeksler tarafından dizinlenmekte ve listelenmektedir. / Bartin University Journal of Faculty of Education is indexed and listed by the following indexes.

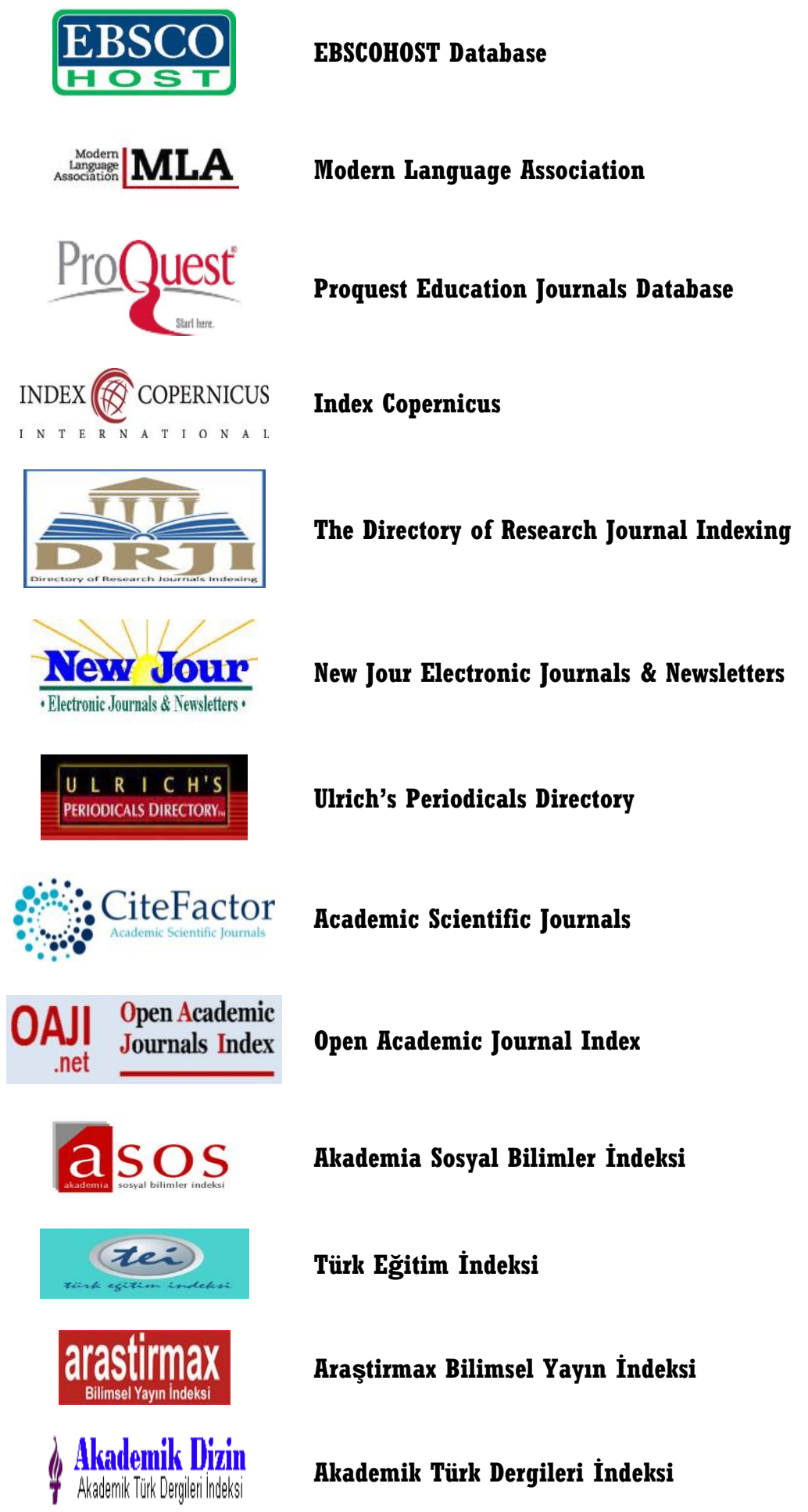


YAYIN DANIŞMA KURULU / EDITORIAL ADVISORYBOARD

Prof. Dr. Ahmet ARIKAN

Prof. Dr. Ahmet GÜNŞEN

Prof. Dr. Ahmet SABAN

Prof. Dr. Aziz KILINÇ

Prof. Dr. Bilgin Ünal iBRET

Prof. Dr. Cemal TOSUN

Prof. Dr. Firdevs GÜNEŞ

Prof. Dr. Firdevs KARAHAN

Prof. Dr. Ahmet KIRKILIÇ

Prof. Dr. Hayati AKYOL

Prof. Dr. Hüseyin ALKAN

Prof. Dr. M. Fatih TAŞAR

Prof. Dr. Mimar TÜRKKAHRAMAN

Prof. Dr. Murat ÖZBAY

Prof. Dr. Ramazan KAPLAN

Prof. Dr. Recai DOĞAN

Prof. Dr. Safure BULUT

Prof. Dr. Sebahattin ARIBAŞ

Prof. Dr. Selahattin TURAN

Prof. Dr. Selma YEL

Prof. Dr. Şefik YAŞAR

Prof. Dr. Yavuz TAŞKESENLIGIL

Doç. Dr. Bahri ATA

Doç. Dr. Çavuş ŞAHIN

Doç. Dr. Çetin SEMERCi

Doç. Dr. Emine KOLAÇ

Doç. Dr. Erol DURAN

Doç. Dr. Eyyüp COŞKUN

Doç. Dr. Kubilay YAZICI

Doç. Dr. Neşe TERTEMiz

Doç. Dr. Nuriye SEMERCi

Doç. Dr. Sabri SIDEKLi

Doç. Dr. Tolga GÜYER
Gazi Üniversitesi

Trakya Üniversitesi

N. Erbakan Üniversitesi

ÇOMÜ

Kastamonu Üniversitesi

Ankara Üniversitesi

Bartın Üniversitesi

Sakarya Üniversitesi

Atatürk Üniversitesi

Gazi Üniversitesi

Dokuz Eylül Üniversitesi

Gazi Üniversitesi

Akdeniz Üniversitesi

Gazi Üniversitesi

Bartın Üniversitesi

Ankara Üniversitesi

ODTÜ

Adıyaman Üniversitesi

Osmangazi Üniversitesi

Gazi Üniversitesi

Anadolu Üniversitesi

Atatürk Üniversitesi

Gazi Üniversitesi

ÇOMÜ

Bartın Üniversitesi

Anadolu Üniversitesi

Uşak Üniversitesi

Mustafa Kemal Üniversitesi

Niğde Üniversitesi

Gazi Üniversitesi

Bartın Üniversitesi

Muğla S. Koçman Üniversitesi

Gazi Üniversitesi 


\section{BU SAYININ HAKEMLERI / REFEREES OFTHIS ISSUE}

Prof. Dr. Ahmet KAÇAR

Prof. Dr. Adnan BAKi

Prof. Dr. Fatma AÇIK

Prof. Dr. Firdevs GÜNEŞ

Prof. Dr. Firdevs KARAHAN

Prof. Dr. Hasan BACANLI

Prof. Dr. Yusuf BUDAK

Doç. Dr. Ali TAŞ

Doç. Dr. Çetin SEMERCi

Doç. Dr. Ebru KILIÇ ÇAKMAK

Doç. Dr. Eyyüp COŞKUN

Doç. Dr. Halit KARATAY

Doç. Dr. Gökhan DEMIRCioĞLU

Doç. Dr. Levent ERASLAN

Doç. Dr. Mehmet Ali ÇAKMAK

Doç. Dr. Mehmet Altan KURNAZ

Doç. Dr. Mustafa ULUSOY

Doç. Dr. Mübin KIYICI

Doç. Dr. Necati HIRÇA

Doç. Dr. Nuriye SEMERCi

Doç. Dr. Orhan AKINOĞLU

Doç. Dr. Özay KARADAĞ

Doç. Dr. Özlem ÇAKMAK

Doç. Dr. Sabri SIDEKLI

Doç. Dr. Yüksel GÖĞEBAKAN

Yrd. Doç. Dr. Abdullah Çağrı BiBBER

Yrd. Doç. Dr. Ahmet YIKMIŞ

Yrd. Doç. Dr. Ahmet AKKAYA

Yrd. Doç. Dr. Ali Rıza ŞEKERCi

Yrd. Doç. Dr. Aslıhan SABAN

Yrd. Doç. Dr. Aynur KOLBURAN GEÇER

Yrd. Doç. Dr. Ayşe Derya IŞIK

Yrd. Doç. Dr. Ayşe GÜLER

Yrd. Doç. Dr. Burcu DUMAN

Yrd. Doç. Dr. Cemal TOSUN

Yrd. Doç. Dr. Çığıl AYKUT

Yrd. Doç. Dr. Devrim AKGÜNDÜZ

Yrd. Doç. Dr. Fulya TOPÇUOĞLU ÜNAL

Yrd. Doç. Dr. Gamze Elif TANINMIŞ

Yrd. Doç. Dr. Güliz AYDIN

Yrd. Doç. Dr. İbrahim GÖKTAŞ

Yrd. Doç. Dr. İlhan YALÇIN
Kastamonu Üniversitesi

Karadeniz Teknik Üniversitesi

Gazi Üniversitesi

Bartın Üniversitesi

Sakarya Üniversitesi

Yıldız Teknik Üniversitesi

Gazi Üniversitesi

Kırıkkale Üniversitesi

Bartın Üniversitesi

Gazi Üniversitesi

Mustafa Kemal Üniversitesi

Abant İzzet Baysal Üniversitesi

Ondokuz Mayıs Üniversitesi

Kırıkkale Üniversitesi

Gazi Üniversitesi

Kastamonu Üniversitesi

Gazi Üniversitesi

Sakarya Üniversitesi

Bartın Üniversitesi

Bartın Üniversitesi

Marmara Üniversitesi

Düzce Üniversitesi

Gazi Üniversitesi

Muğla Sıtkı Koçman Üniversitesi

İnönü Üniversitesi

Kastamonu Üniversitesi

Abant İzzet Baysal Üniversitesi

Adıyaman Üniversitesi

Dumlupınar Üniversitesi

Konya Üniversitesi

Kocaeli Üniversitesi

Bartın Üniversitesi

Kırıkkale Üniversitesi

Bartın Üniversitesi

Bartın Üniversitesi

Gazi Üniversitesi

İstanbul Aydın Üniversitesi

Dumlupınar Üniversitesi

Gazi Üniversitesi

Ordu Üniversitesi

Adnan Menderes Üniversitesi

Ankara Üniversitesi 
Yrd. Doç. Dr. M. Sani ADIGÜZEL

Yrd. Doç. Dr. Mehmet Diyaddin YAŞAR

Yrd. Doç. Dr. Mehmet UMUZDAŞ

Yrd. Doç. Dr. Metin DENIZ

Yrd. Doç. Dr. Murat GENÇ

Yrd. Doç. Dr. Nail iLHAN

Yrd. Doç. Dr. Nalan OKAN AKIN

Yrd. Doç. Dr. Nuray MAMUR

Yrd. Doç. Dr. Özcan KARAASLAN

Yrd. Doç. Dr. Özge GÜN

Yrd. Doç. Dr. Sedat BALYEMEZ

Yrd. Doç. Dr. Semra KIRANLI GÜNGÖR

Yrd. Doç. Dr. Sibel SADI

Yrd. Doç. Dr. Suad SAKALLI GÜMÜŞ

Yrd. Doç. Dr. Sultan Bilge KARA

Yrd. Doç. Dr. Süleyman AVCI

Yrd. Doç. Dr. Şenel ELALDI

Yrd. Doç. Dr. Şeyda GÜL

Yrd. Doç. Dr. Tolga KABACA

Yrd. Doç. Dr. Tuncay Yavuz ÖZDEMiR

Yrd. Doç. Dr. Yakup DOĞAN

Dr. Hayriye Tuğba ÖZTÜRK
İstanbul Aydın Üniversitesi

Kilis 7 Aralık Üniversitesi

Gaziosmanpaşa Üniversitesi

Bartın Üniversitesi

Düzce Üniversitesi

Kilis 7 Aralık Üniversitesi

Niğde Üniversitesi

Pamukkale Üniversitesi

Marmara Üniversitesi

Bartın Üniversitesi

Bartın Üniversitesi

Eskişehir Osmangazi Üniversitesi

Kafkas Üniversitesi

Mustafa Kemal Üniversitesi

Okan Üniversitesi

Marmara Üniversitesi

Cumhuriyet Üniversitesi

Atatürk Üniversitesi

Pamukkale Üniversitesi

FIrat Üniversitesi

Kilis 7 Aralık Üniversitesi

Ankara Üniversitesi 


\section{IÇINDEKILER / CONTENTS}

\section{Prof. Dr. Firdevs GÜNEŞ}

Konuşma Öğretimi Yaklaşım ve Modelleri

Speech Teaching Approaches and Models

doi number: 10.14686/BUEFAD.201416205

\section{Barış ÇUKURBAŞı - Prof. Dr. Aytekin IŞMAN}

Öğretmen Adaylarının Dijital Yerli Özelliklerinin Incelenmesi (Bartın Üniversitesi Örneği)

Examination of Teacher Candidates' Digital Natives Features (Example of Bartın University)

doi number: 10.14686/BUEFAD.201416206

Yrd. Doç. Dr. Süleyman GÖKSOY - Doç. Dr. Engin ASLANARGUN

Denetim Sürecinde Eğitim Denetmenlerinin Davranışları

Behaviours of Supervisors in the Process of Supervision

$55-77$

doi number: 10.14686/BUEFAD.201416207

Arş. Gör. Yunus ÖZYURT - Doç. Dr. Altay EREN

Fen Bilgisi Öğretmen Adaylarının Öğretmenlik Mesleğine ve Kopya Çekmeye Yönelik Tutumlarının Görünümü

Profiles of Pre-Service Science Teachers' Attitudes towards the Teaching Profession and Cheating doi number: 10.14686/BUEFAD.201416208

\section{Yrd. Doç. Dr. Sefa DÜNDAR}

The Investigation of Spatial Skills of Prospective Teachers with Different Cognitive

Bilissel Stilleri Farklı Ogretmen Adaylarının Uzamsal Becerilerinin Incelenmesi

doi number: 10.14686/BUEFAD.201416209

Yrd. Doç. Dr. Abdulkerim KARADENiz

Eleştirel Okuma Özyeterlilik Algısı Ölçeğinin Geçerlilik ve Güvenirlik Çalışması

Critical Reading Self-Efficacy Perception Scale Validity and Reliability Study

doi number: 10.14686/BUEFAD.201416210

Yrd. Doç. Dr. Ayşen KARAMETE - Öğr. Gör. Hüseyin GÜNEŞ

İlköğretim Seçmeli Satranç Dersi Başlangıç Düzeyi Birinci Basamak Bilgisayar Destekli Öğretim Tasarımı

Primary School First Grade Beginner Level Chess Course Computer-Aided Instructional Design

doi number: 10.14686/BUEFAD.201416211

Doç. Dr. Fahri TEMizYÜREK - Arş. Gör. Arzu ÇEVIK

Mustafa Ruhi Şirin'in Çocuk Edebiyatı Sahasındaki Eserlerinin Dil ve Kavram Bağlamında İncelenmesi

Examination of Mustafa Ruhi Sirin's Works in Field of Children's Literature According to Context of Language

Concept

doi number: 10.14686/BUEFAD.201416212

Dr. Gizem KARAOĞLAN YILMAZ - Dr. Ramazan YILMAZ - Arş. Gör. Barış SEZER

Üniversite Öğrencilerinin Güvenli Bilgi ve İletişim Teknolojisi Kullanım Davranışları ve Bilgi Güvenliği Eğitimine Genel Bir Bakış

Secure Information and Communication Technology Usage Behavior of University Students and an Overview

to Information Security Training

$176-199$

doi number: 10.14686/BUEFAD.201416213 


\section{IÇINDEKILER / CONTENTS}

\section{Yrd. Doç. Dr. Erdal TAŞLIDERE}

Kavramsal Değişim Yaklaşımının Doğru Akım Devreleri Konusundaki Kavram Yanılgılarının Giderilmesine Etkisi

Effect of Conceptual Change Instruction on Remedying Misconceptions Concerning Direct Current Circuits doi number: 10.14686/BUEFAD.201416214

\section{Dr. H. Tuğba ÖzTÜRK}

Küreselleşme ve Ağ Toplumları Odağında Bilgi ve Illetişim Teknolojileri ile Eğitim Education with Information and Communication Technologies in the Scope of Globalisation and Network Society doi number: 10.14686/BUEFAD.201416215

Yrd. Doç. Dr. Serkan TiMUR - Şirin YILMAZ - Yrd. Doç. Dr. Betül TiMUR Fen ve Teknoloji Öğretmenleri İle Öğretmen Adaylarının Fen Deneylerinin Amaçlarını Kavramaya Yönelik Tutumlarının İncelenmesi Investigating Science and Technology Teachers' and Pre-Service Teachers' Attitudes towards Understanding the Objectives of Science Experiments doi number: 10.14686/BUEFAD.201416216

\section{Fazilet Eda YILMAZ - Gülşah TOPALOĞLU - Mustafa AKYÜZLÜER}

Grupla Yapılan Müzik Etkinliğinin Otizmli Çocukların Sosyal Becerilerine Etkisinin Betimlenmesi

Description of the Effect of Musical Activity with Group on Social Skills of Children with Autism doi number: 10.14686/BUEFAD.201416217

Yrd. Doç. Dr. Özcan Erkan AKGÜN - Şirin KÜçÜK

Barış ÇUKURBAŞI - İsmail TONBULOĞLU

Sözel veya Görsel Baskın Öğrenme Stilini Belirleme Ölçeği Türkçe Formunun Geçerlik ve Güvenirlik Çalışması

Validity and Reliability Study of the Visual versus Verbal Style of Processing Scale Turkish Form doi number: 10.14686/BUEFAD.201416218

Arş. Gör. Ruhşen ALDEMiR - Doç. Dr. Enver TATAR Teknoloji Destekli Matematik Eğitimi Hakkında Yayınlanan Makalelerinin İncelenmesi An Analysis of Articles on Technology Assisted Mathematics Education doi number: 10.14686/BUEFAD.201416219

İsmail TONBULOĞLU - Prof. Dr. Aytekin IŞMAN

Öğretmenlerin Sosyal Ağları Kullanım Profillerinin İncelenmesi

Exploring Teachers' Social Network Usage

doi number: 10.14686/BUEFAD.201416220

Arş. Gör. Dr. Osman çiMEN - Prof. Dr. Mehmet YILMAZ Dönüşümsel Öğrenme Kuramına Dayalı Çevre Eğitiminin Biyoloji Öğretmen Adaylarının Çevre Sorunlarına Yönelik Algılarına Etkisi The Influence of Transformative Learning Based Environmental Education on Preservice Biology Teachers' Perception of Environmental Problems doi number: 10.14686/BUEFAD.201416221

Doç. Dr. İ. Halil TÜRKER - Yrd. Doç. Dr. Fatih ÖZDEMiR Resim-İş Eğitimi Programları Grafik Ana Sanat Ders İçerikleri ve İşleniş Biçimleri Course Outlines and Teaching Styles at Graphic Design Lessons at Fine Arts Education Departments doi number: 10.14686/BUEFAD.201416222 


\section{IÇINDEKILER / CONTENTS}

\section{Yrd. Doç. Dr. Süreyya GENÇ}

Sanat Eğitiminde Eğitsel Oyunların Önemi

Importance of Educational Games in Arts Education

doi number: 10.14686/BUEFAD.201416223

Doç. Dr. Lale HÜSEYNOVA

Müzik Öğretmenliği Bölümü Öğrencilerinin Keman Çalma Performanslarını Etkileyen Bazı Değişkenler

Some Variables that Affect the Violin - Playing Performance of Students in the Department of Music Teaching doi number: 10.14686/BUEFAD.201416224

\section{Yrd. Doç. Dr. Vafa SAVAŞKAN}

Eğitim Fakültesi Öğrencilerinin Günlük Tutma Alışkanlıklarının Öğrenci Görüşleri Doğrultusunda İncelenmesi

Investigate the Logging Habits of the Faculty of Education Students in Terms of Students' Opinion doi number: 10.14686/BUEFAD.201416225

Arş. Gör. Melehat GEZER - Prof. Dr. İbrahim Fevzi ŞAHIN

Yrd. Doç. Dr. Meral ÖNER SÜNKÜR - Arş. Gör. Elif MERAL

8. Sınıf Türkiye Cumhuriyeti İnkılâp Tarihi ve Atatürkçülük Dersi Öğretim Programı Kazanımlarının Revize Edilmiş Bloom Taksonomisine Göre Değerlendirilmesi

An Evaluation of the Outcomes of the 8th Grade History of Turkish Revolution and Kemalism Lesson According to Revized Bloom's Taxonomy doi number: 10.14686/BUEFAD.201416226

Prof. Dr. Firdevs GÜNEŞ - Doç. Dr. Coşkun ARSLAN - Arş. Gör. Ayşe ELiÜşÜK Atılganlık Eğitiminin Üniversite Öğrencilerinin Kişiler Arası Problem Çözme, Algılanan Sosyal Destek ve Atılganlık Düzeyleri Üzerine Etkisi 


\title{
Fen Bilgisi Öğretmen Adaylarının Öğretmenlik Mesleğine ve Kopya Çekmeye Yönelik Tutumlarının Görünümü*
}

\author{
Arş. Gör. Yunus ÖZYURT \\ Abant İzzet Baysal Üniversitesi \\ Eğitim Fakültesi \\ yunusozyurt@ibu.edu.tr
}

\author{
Doç. Dr. Altay EREN \\ Abant İzzet Baysal Üniversitesi \\ Eğitim Fakültesi \\ eren_a@ibu.edu.tr
}

Özet: Bu araştırmanın amacı fen bilgisi öğretmen adaylarının kopya çekmeye yönelik tutumları ile öğretmenlik mesleğine yönelik tutumlarının görünümünün incelenmesidir. Araştırmanın verileri tarama yöntemine dayalı olarak elde edilmiş ve analizlerde keşfe dayalı ilişkisel desen benimsenmiştir. Araştırmada, "Kopya Çekmeye Yönelik Tutum Ölçeği" ve "Öğretmenlik Mesleğine Yönelik Tutum Ölçeği" veri toplama araçları olarak kullanılmıştır. Araştırmanın örneklemini 2012-2013 Eğitim-Öğretim yılı güz döneminde Türkiye'nin Batı Karadeniz bölgesinde yer alan bir üniversitenin Eğitim Fakültesi Fen Bilgisi Öğretmenliği bölümünde öğrenim gören, yaklaşık 600 öğretmen adayı arasından yansız atamayla seçilen 250 öğretmen adayı oluşturmuştur. Korelasyon analizinin sonucu öğretmen adaylarının öğretmenlik mesleğine yönelik tutumlarının kopya çekmeye yönelik tutumlarıyla zayıf, ancak anlamlı düzeyde ve negatif yönlü ilişkilendiğini göstermiştir. Daha önemlisi, küme analizi sonuçları öğretmen adaylarının söz konusu tutumlarının iki anlamlı küme örüntüsüyle açıklanabileceğini göstermiştir.

Anahtar Sözcükler: Öğretmenlik mesleği, kopya, tutum, fen bilgisi öğretmen adayları

\section{Profiles of Pre-Service Science Teachers' Attitudes towards the Teaching Profession and Cheating}

\begin{abstract}
The aim of this study is to examine the profiles of pre-service science teachers' attitudes towards the teaching profession and cheating. The data were collected based on the survey method, and exploratory correlational design was adopted for the data analysis. The Attitudes towards Cheating Scale and Attitudes towards Teaching Profession Scale were used as the data collection tools in the study. The sample of the study contained 250 pre-service science teachers who were randomly sampled among 600 pre-service teachers majoring in Science Teacher Education Program in the Faculty of Education at a university located in the north-west of the Black Sea region in Turkey. The result of correlational analysis showed that the pre-service science teachers' attitudes towards the teaching profession weakly, yet significantly and negatively related to their attitudes towards cheating. More importantly, the results of cluster analysis revealed that the pre-service teachers' attitudes could be explained through two meaningful cluster patterns.
\end{abstract}

Key Words: Teaching profession, cheating, attitude, pre-service science teachers

Bu makale, 5-7 Eylül 2013 tarihleri arasında Eskişehir Osmangazi Üniversitesi'nde düzenlenen 22. Ulusal Eğitim Bilimleri Kurultayı'nda sunulan aynı başlıklı bildirinin genişletilmiş halidir. 


\section{GíRiş}

Eğitimin temel unsurlarından biri de hiç kuşkusuz ölçme ve değerlendirmedir. Ölçme ve değerlendirme sürecinin hatalardan arınmış olması ise son derece önemli bir özelliktir. Nitekim ölçme sonuçlarının sabit, sistematik ve rastgele hatalardan arınmış olmasının gereği ve önemi konuyla ilgili literatürde sıklıkla vurgulanmaktadır (Atılgan, 2005; Bahar, Nartgün, Durmuş ve Bıçak, 2010; Kimberlin ve Winterstein, 2008). Ancak, ölçümü gerçekleştiren/araştırmayı yapan kişilerin kontrolünde olmayan (öğrencilerin içinde bulundukları duygu durumları, geçmiş yaşantıların olası etkileri, inançlar vb.) ve/veya ölçmeye temel oluşturan verilerin sınavlardan hemen önce toplanması, öğrencilere kavramlar hakkında yeterli bilgi verilmemesi gibi işlem yoluyla ilgili nedenlere bağlı olarak ölçme ve değerlendirme sürecine farklı kaynaklardan hata karışabilmektedir. Bu hata kaynaklarından bir tanesi de, öğrencilerin başarı durumları hakkındaki değerlendirme sürecini olumsuz yönde etkileyerek hatalı kararlar alınmasına neden olabilen 'kopya çekme' davranışıdır (Miller, Shoptaugh ve Wooldridge, 2011; Semerci, 2004; Seven ve Engin, 2008; Topcu ve Uzundumlu, 2011).

Türk Dil Kurumu Sözlüğünde kopya, "bir sınavda soruları cevaplamak için başka birinden veya yerden yararlanma" şeklinde tanımlanmaktadır. Buna göre, kopya çekme öğrencilerin özellikle sınavlarda kendilerine haksız biçimde avantaj sağlamalarının etik olmayan bir yolu olarak belirginleşmektedir (Erarslan, 2011). Ancak, konuyla ilgili literatürde söz konusu 'yolun' dikkate değer ölçüde tercih edildiğine yönelik önemli sayıda kanıt bulunmaktadır (Enker, 1987; Lawson, 2004; Whitley, Nelson ve Jones, 1999). Örneğin, Sherrill, Salisbury, Horowitz ve Friedman'ın (1971) 138 üniversite öğrencisi üzerinde yaptığı çalışmada, öğrencilerin büyük çoğunluğunun ( $n=91$ ) kopya çektiğine yönelik bulgular elde edilmiştir. Ayrıca, araştırmada kopya çektiği tespit edilen öğrencilerin yine dikkate değer bir çoğunluğunun ( $n=29$ ) hemen her fırsatta kopya çektiği de tespit edilmiştir. Benzer biçimde, Aydoğan (2008) Rus öğrencilerin \% 61 inin, Tatar öğrencilerin ise \% 58'sinin, 'insanlar başarılı olmak için bazen yalan söylemek veya kopya çekmek zorundadır' ifadesine katıldıkları sonucuna ulaşmıştır. Josephson Etik Enstitüsü (2004; aktaran: Aydoğan, 2008) tarafından yapılan bir araştırmada, ABD'li gençlerin bu maddeye katılma oranının \% 42 olduğu saptanmıştır.

Türkiye'de kopya çekme ile ilgili bugüne kadar görece az sayıda araştırma yapılmıştır. Ancak, bu araştırmalardan elde edilen bulgular yukarıda değinilen bulgularla paralellik göstermektedir. Örneğin, Çetin (2007) tarafından gerçekleştirilen ve toplam 300 üniversite 
öğrencisini kapsayan bir çalışmada, öğrencilerin $\% 75$ 'inin en azından bir dersten kopya çektiği tespit edilmiştir. Araştırmada ayrıca, erkek öğrencilerin kız öğrencilere göre kopyaya karşı daha olumlu tutuma sahip oldukları ve sınıf düzeyi arttıkça kopya çekmeye yönelik eğilimin arttığına ilişkin bulgular da elde edilmiştir. Lüle Mert (2012)'in yaptığı 140 üniversite son sınıf öğrencisini kapsayan benzer bir çalışmada, öğrencilerin \%71'i kopya çektiklerini belirtmişlerdir.

Semerci (2004) tarafından kopya çekme sorunu ile ilgili olarak 73 tıp fakültesi beşinci ve altıncı sınıf öğrencisi üzerinde yapılan araştırma sonuçları, öğrencilerin yalnızca kopya çekme davranışlarına ilişkin eğilimlerinin yüksek olmadığını, aynı zamanda kopya çekmenin yaygın bir davranış eğilimi olduğuna inandıklarını göstermiştir. Benzer bulgular, farklı mesleki bağlamlara yönelik olarak da elde edilmiştir. Örneğin, Semerci ve Sağlam'ın (2005) 151 polis meslek yüksekokulu ikinci sınıf öğrencisinin örneklemini oluşturduğu çalışmalarında, öğrencilerin kopya çekmeye yönelik olumlu tutumlara sahip oldukları saptanmıştır. Ayrıca, öğrencilerin büyük çoğunluğu (\%60) bireyin gelişiminden çok, nota önem verilmesinin sınavda kopya çekmeye yönelmelerinin temel sebebi olduğunu, sınıf arkadaşlarının kopya çektiğini düşündüklerini ve en çok başvurdukları kopya çekme yönteminin başkalarının kâğıdına bakmak olduğunu ifade etmişlerdir. Benzer biçimde, Seven ve Engin (2008) öğrencilerin yüksek not alamama kaygılarının, kopya çekme eylemini adeta keyif verici bir etkinlik olarak görmeye başlamalarının ve özellikle dersten kalma korkularının kopya çekme nedenleri arasında önemli yer tuttuğunu belirtmişlerdir.

Durmuşçelebi'nin (2011) toplam 867 lise ve üniversite öğrencisini kapsayan çalışmasında, öğrencilerin dörtte üçünün sınavda başkalarının yazdıklarını aynen geçirme ve yasak olan notlardan (yazılı dokümanlardan) yararlanmayı kopya çekme davranışı olarak algıladıkları saptanmıştır. Araştırmanın dikkat çekici bulgularından bir diğeri ise, her dört öğrenciden birinin bu davranışları kopya olarak algılamamasıdır. Nitekim bununla tutarlı olarak, araştırmada yer alan öğrencilerin önemli bir bölümü ödevlerini başka birine yaptırmayı ve bir cümleyi kaynak göstermeksizin alıntılamayı kopya çekme olarak algılamadıklarını ifade etmişlerdir.

Yukarıda yapılan açıklamalardan hareketle, kopya çekme davranışının yalnızca Türkiye'de değil Rusya ve ABD gibi dünyanın farklı ülkelerindeki lise ve üniversite öğrencileri arasında da yaygın biçimde benimsenen bir davranış biçimi olduğu söylenebilir. Bu konu ile ilgili kapsamlı bir gözden geçirme için McCabe, Treviño ve Butterfield (2001) tarafından yapılan çalışma incelenebilir. Bununla birlikte, ödevleri başkasına yaptırma ya da bir cümleyi atıfta 
bulunmaksızın kullanma gibi davranışların, öğrenciler tarafından kopya çekme kavramının kapsamı dışında algılandığı çıkarımında da bulunulabilir. Bunun anlamı, esasen kopya çekme davranışları içerisinde yer alan eylemlerin, öğrenciler tarafından giderek olumsuz eylemler olarak algılanmaktan çıktığıdır. Bu çıkarım, kopya çekmenin eğitim-öğretim sürecinde öğrenmeyi olumsuz yönde etkileyen ve yetersiz bilgi birikimine sahip kitlelerin oluşmasına neden olan bir davranış biçimi olduğu bilgisiyle birlikte ele alındığında, adeta alarm veren bir problem durumuna işaret etmektedir. Nitekim söz konusu kitlelerin ilerleyen eğitim yaşantıları sürecinde bilgi eksiklikleri hızla büyümekte, analiz ve sentez düzeyinde profesyonel bilgi üretmeleri ve mesleki kazanımları, ülke problemlerine çözüm üretme ve ülke ekonomisine katkı sağlama düzeyleri de azalmaktadır (Topcu ve Uzundumlu, 2011).

Bu noktada, eğitim ortamlarında kopya çekme davranışlarının azaltılmasında ceza verme gibi yaptırıma dayalı uygulamalardan çok, öğrencilerde öğrenmenin çabaya bağlı olduğuna ilişkin inançların geliştirilmesinin, öğrenme amaçlarını benimsemelerine yardımcı olacak öğretim uygulamalarının ve katılıma açık bir yaklaşımla belirlenecek etik standartların etkili olduğu söylenebilir (Anderman ve Midgley, 2004; Miller vd., 2011). Örneğin, Anderman ve Midgley (2004) öğrencilerin matematik dersine yönelik kopya çekme davranışlarının ortaokul ve lise aşamalarındaki görünümleri ile öğretmen-öğrenci etkileşimi aracılığıyla oluşan sınıf ortamlarının başarı amaç yapıları arasındaki ilişkileri inceledikleri çalışmalarında, söz konusu aşamalarla kopya çekme davranışları ve sınıflardaki başarı amaç yapıları arasında anlamlı bir etkileşim saptamışlardır. Spesifik olarak araştırmada, ortaokuldayken matematiği öğrenme amaç odağının yüksek olduğu, lise aşamasında ise öğrenme amaç odağının düşük olduğu sınıf ortamlarında öğrenen öğrencilerin, ortaokuldayken matematiği öğrenme amaç odağının düşük olduğu, lise aşamasında ise öğrenme amaç odağının yüksek olduğu sınıf ortamlarında öğrenen öğrencilere göre derslerde daha sık kopya çektikleri saptanmıştır.

Dolayısıyla, öğrencilerin öğrenme amaçlarını benimsemelerine yardımcı olacak öğretim uygulamaları gibi önemli uygulamaların hayata geçirilmesinde, öğretmenlerin kopya çekmeye yönelik tutumlarına ve öğretmenlik kariyer sürecinin en erken aşamasını oluşturan öğretmen eğitim sürecinin niteliğine odaklanılması gerektiği söylenebilir. Buna rağmen, öğretmen adaylarının kopya çekmeye yönelik davranışları ve tutumları görece az sayıda araştırmanın odak noktasını oluşturmuştur. Üstelik beklenenin aksine, bu araştırmalardan elde edilen bulgular öğretmen adaylarının kopya çekmeye yönelik tutumlarının ve daha da önemlisi davranışlarının tamamen olumsuz bir eksende yer almadığını göstermiştir. 
Örneğin, Akdağ ve Güneş (2002) tarafından gerçekleştirilen ve toplam 237 öğretmen adayını kapsayan bir çalışmada, öğretmen adaylarının dikkate değer bir çoğunluğunun sınavlarda öğrenciler arasında soruların ve cevapların alınması $(n=153)$ ve verilmesinin $(n=146)$ kopya çekme davranışı olarak algılanmadığı saptanmıştır. Kopya çekme davranışının sıklığı cinsiyet ve sınıf düzeyine göre analiz edildiğinde ise, kızlar lehine anlamlı bir farklılık olduğu ve 4. sınıflardaki öğretmen adaylarının kopya çekme davranışlarının 2. sınıflardaki öğretmen adaylarına göre daha az olduğu gözlenmiştir. Bozdoğan ve Öztürk (2008)'ün 194 öğretmen adayının katılımıyla gerçekleştirdiği benzer bir çalışmada, öğretmen adaylarının büyük çoğunluğunun ( $n=140$ ) üniversitede en azından bir defa kopya çektiği bulgusu elde edilmiştir. Öğretmen adayları kendilerini kopya çekmeye yönelten en önemli nedenleri ise sırasıyla, "sistemde not önemli olduğu için", "bilgi değil, dersten geçmek önemli olduğu için" ve "dersten kalma korkusu duyduğum için" şeklinde ifade etmişlerdir. Yangın ve Kahyaoğlu (2009) 190 ilköğretim öğretmen adayı üzerinde yaptığı çalışmada, erkek öğretmen adaylarının kopya çekme eğiliminin kız öğretmen adaylarına göre anlamlı düzeyde daha fazla olduğunu saptamıştır. Ayrıca öğretmen adaylarının \% 81,9'u nadiren de olsa kopya çektiklerini ifade etmişlerdir. Er ve Gürgan (2011) okulöncesi öğretmenliği, matematik öğretmenliği, sınıf öğretmenliği, sosyal bilgiler öğretmenliği ve fen bilgisi öğretmenliği alanlarında öğrenim gören toplam 649 öğretmen adayını kapsayan çalışmalarında, öğretmen adaylarının kopya çekmeye yönelik tutumları açısından kız öğretmen adayları lehine anlamlı bir farklılık saptamışlardır. Sınıf düzeyine göre yapılan analizlerde ise anlamlı bir fark olmadığı görülmüştür. Önemli olarak, araştırmada fen bilgisi öğretmen adaylarının kopya çekmeye yönelik tutumlarının, hem sınıf öğretmenliği hem de okulöncesi alanlarında öğrenim gören öğretmen adaylarının kopya çekmeye yönelik tutumlarından anlamlı düzeyde daha olumsuz olduğu bulgusu da elde edilmiştir. Fen bilgisi öğretmen adaylarının kopya çekmeye yönelik tutumları ile diğer alanlarda öğrenim gören öğretmen adaylarının (matematik öğretmenliği ve sosyal bilgiler öğretmenliği) kopya çekmeye yönelik tutumları arasında ise anlamlı farklılıklar saptanmamıştır. Buna göre, fen bilgisi öğretmen adaylarının kopya çekmeye yönelik olarak tamamen olumsuz tutumlara sahip olmadıkları ifade edilebilir.

Yukarıda değinilen araştırmalar öğretmen adaylarının kopya çekmeye yönelik tutumları ile davranışlarına yönelik dikkate değer bulgular ortaya koymalarına rağmen, bu araştırmalarda öğretmen adaylarının öğretmenlik mesleğine yönelik tutumlarının kopya çekmeye yönelik tutumlarıyla ve/veya davranışlarıyla bir arada incelenmemiş olması önemli bir sınırlılık olarak göze çarpmaktadır. Nitekim eleştirel bakış açısına sahip olan bir birey, öğretmen adaylarının 
örneklemini oluşturduğu bu araştırmalardan elde edilen bulguların, öğretmenlik mesleğinin etik kuralların davranışa dönüştürülmesi gereken bir meslek olması (Çelikten, Şanal ve Yeni, 2005; Hiebert, Gallimore ve Stigler, 2002; Richardson ve Watt, 2006; Seferoğlu, 2004) ve henüz öğretmen kimliğini tam anlamıyla oluşturmamış ya da mesleğe yönelik olumsuz tutumlara sahip öğretmen adaylarının kopya çekme gibi, mesleğin doğasıyla çelişen davranışlara yönelmesinin beklenebileceği iddiasında bulunabilir. Öğretmenlik mesleği açısından önemli bir vurguya sahip olan bu iddia, öğretmen adaylarının öğretmenlik mesleğine yönelik tutumlarının kopya çekmeye yönelik tutumlarıyla bir arada incelenmesinin önemine ve gereğine işaret etmektedir.

Ancak, konuyla ilgili literatürde öğretmen adaylarının öğretmenlik mesleğine yönelik tutumlarının incelendiği çok sayıda araştırma bulunmasına rağmen (bkz. Aydın ve Sağlam, 2012; Özbek, Kahyaoğlu ve Özgen, 2007; Tanel, Kaya Şengören ve Tanel, 2007; Üstüner, 2006; Yüksel, 2004), öğretmen adaylarının kopya çekmeye yönelik tutumlarıyla öğretmenlik mesleğine yönelik tutumlarının bir arada incelendiği bir çalışmaya rastlanmamıştır. Üstelik bu çalışmalarda öğretmen adaylarının öğretmenlik mesleğine yönelik tutumları kişi merkezli bir yaklaşımla değil, değişken merkezli bir yaklaşımla incelenmiştir. Örneğin, Özbek ve arkadaşlarının (2007) birinci ve dördüncü sınıflarda öğrenim gören toplam 470 öğretmen adayı ile gerçekleştirdikleri çalışmada, öğretmen adaylarının mesleğe yönelik tutumlarının olumlu olduğu ve kız öğretmen adaylarının erkek öğretmen adaylarına göre daha olumlu tutumlara sahip oldukları saptanmıştır.

Tanel vd. (2007) 1, 2, 3, 4 ve 5. sınıflarda öğrenim gören 160 fizik öğretmen adayı ile yaptıkları çalışmada, öğretmen adaylarının öğretmenlik mesleğine yönelik tutumlarının genel anlamda olumlu olduğunu gözlemişlerdir. Araştırmada sınıf düzeyine bağlı olarak yapılan analizler aracılı̆̆ıla da birinci ve dördüncü sınıflar arasında ve dördüncü ve beşinci sınıflar arasında gözlenen anlamlı farkların dördüncü sınıflar lehine olduğu saptanmıştır.

Diğer taraftan, Hacıömeroğlu ve Şahin Taşkın'ın (2010) 110 öğretmen adayı ile gerçekleştirdikleri benzer bir çalışmada öğretmenlik mesleğine yönelik tutumların cinsiyete göre anlamlı bir farklılık göstermediği saptanmıştır. Yüksel'in (2004) tezsiz yüksek lisans öğrencileri üzerinde yaptığı çalışmada öğrencilere programa başlarken ve mezun olurken öğretmenlik mesleğine yönelik tutum ölçeği uygulanmış ve programın mesleğe yönelik tutumlar üzerinde anlamlı bir etkisinin olmadığı tespit edilmiştir. Pektaş ve Kamer'in (2011) fen bilgisi öğretmen adaylarının öğretmenlik mesleğine yönelik tutumlarını belirlemeye yönelik 
olarak yaptıkları çalışmada, hem kız hem de erkek öğretmen adaylarının olumlu tutumlara sahip oldukları bulgusuyla birlikte, kız öğretmen adaylarının erkek öğretmen adaylarına göre daha olumlu bir tutuma sahip olduğu ve birinci ve ikinci sınıflarda öğrenim gören öğrencilerin dördüncü sınıflarda öğrenim gören öğrencilere göre daha olumlu tutumlara sahip oldukları da gözlenmiştir.

Daha önce vurgulandığı gibi, bu araştırmalar aracılığıyla elde edilen bulguların, değişken merkezli analizlerden hareketle elde edilmiş olmaları ve öğretmen adaylarının kopya çekmeye yönelik tutumlarının dikkate alınmamış olması konuyla ilgili literatüre yönelik katkılarını sınırlamaktadır. Daha açık bir ifadeyle, değişken merkezli analizlerde belirli bir grubun aritmetik ortalamasına dayalı olarak yapılan analizler, herhangi bir değişkene (örneğin öğretmenlik mesleğine yönelik tutum) ilişkin görünümün içerisindeki çeşitliliğin (örneğin yüksek, orta ve düşük düzeyde olumlu tutum) açığa çıkmasını engellemekte (Fryer ve Elliot, 2007) ve dolayısıyla da gruba ilişkin spesifik yorumlardan çok, genel yorumlara imkan vermektedir. Bu nedenle, bu araştırmada öğretmen adaylarının öğretmenlik mesleğine ilişkin görünümü yalnızca değişken merkezli değil (korelasyon analizi), aynı zamanda kişi merkezli bir yaklaşımla da (küme analizi) incelenmiştir. Analizlerde ayrıca, bundan önceki araştırmalarda önemli etkilerinin gözlenmesi nedeniyle, cinsiyet ve sınıf düzeyi değişkenleri de dikkate alınmıştır. Dolayısıyla, bu araştırmadan elde edilecek olan bulguların bundan önceki araştırmalardan önemli ölçüde farklılaştığı ve bu farklılı̆ın araştırmanın konuyla ilgili literatüre ilişkin olası katkılarını arttıracağı ifade edilebilir.

Üstelik daha önce belirtildiği gibi, konuyla ilgili literatürde öğretmen adaylarının öğretmenlik mesleğine yönelik tutumları ile kopya çekmeye yönelik tutumlarının birlikte incelendiği bir çalışmaya rastlanmamıştır. Oysa söz konusu inceleme en azından bir nedenden dolayı önemlidir. Öğretmen adaylarının kopya çekmeye yönelik tutumlarına ilişkin olarak bundan önce gerçekleştirilen araştırmalardan elde edilen bulgular, kopya çekmeye yönelik tutumlarının kısmen de olsa olumlu bir eksende yer aldığını göstermektedir (Akdağ ve Güneş, 2002; Er ve Gürgan, 2011; Yangın ve Kahyaoğlu, 2009). Diğer taraftan, öğretmen adaylarının öğretmenlik mesleğine yönelik tutumlarının incelendiği araştırmalardan elde edilen bulgular, mesleğe yönelik tutumlarının da olumlu bir eksende yer aldığını göstermektedir (Akpınar, Yıldız ve Ergin, 2006; Özbek vd., 2007; Tanel vd., 2007). Bu bulgular birlikte ele alındığında, özünü dürüstlük ve çaba gibi unsurların oluşturduğu bir meslek olan öğretmenliğe yönelik önemli bir çelişkiye işaret etmektedir. Dolayısıyla, bu araştırmadan elde edilecek olan bulgular söz konusu 
çelişkinin çözümüne yönelik önemli bir katkı sağlayabilir. Ayrıca, bu araştırmadan elde edilecek olan bulgular kopya çekme ve öğretmenlik mesleğine ilişkin tutumlar gibi önemli bireysel farklılık değişkenlerinin öğretmen eğitim programlarında dikkate alınmasına ve söz konusu tutumların istenen yönde değiştirilmesine yönelik etkinliklerin geliştirilmesine de olanak sağlayabilir.

\subsection{Amaç ve Sorular}

$\mathrm{Bu}$ araştırmanın amacı fen bilgisi öğretmen adaylarının kopya çekmeye yönelik tutumları ile öğretmenlik mesleğine yönelik tutumlarının görünümünün incelenmesidir. Bu amaç doğrultusunda üç araştırma sorusuna cevap aranmıştır.

1. Fen bilgisi öğretmen adaylarının kopya çekmeye yönelik tutumları ve öğretmenlik mesleğine yönelik tutumları cinsiyet ve sınıf düzeyine göre farklılaşmakta mıdır?

2. Fen bilgisi öğretmen adaylarının kopya çekmeye yönelik tutumları ile öğretmenlik mesleğine yönelik tutumları arasında anlamlı bir ilişki var mıdır?

3. Fen bilgisi öğretmen adaylarının kopya çekmeye yönelik tutumları ile öğretmenlik mesleğine yönelik tutumlarının görünümü nedir?

\section{YÖNTEM}

$\mathrm{Bu}$ araştırma betimsel bir araştırma niteliğindedir ve yöntemini tarama yöntemi oluşturmuştur. Araştırmanın deseni ise, incelemeye konu olan değişkenler arasındaki ilişkilere yönelik az sayıda kanıt bulunduğu ya da hiç kanıt bulunmadığı durumlarda benimsenen keşfe dayalı ilişkisel desendir (Büyüköztürk, Kılıç Çakmak, Akgün, Karadeniz ve Demirel, 2011; Fraenkel, Wallen ve Hyun, 2012).

\subsection{Gerekçe ve Örneklem}

Sayısal ve kavramsal içeriği yoğun olan matematik ve fen bilgisi gibi dersler, öğrenciler tarafından 'zor dersler' ya da 'öğrenilmesi kısmen de olsa yeteneğe bağlı olan dersler' olarak algılanmakta ve bu algılama öğrencileri bu derslerde, diğer derslere göre kopya çekmeye daha fazla yönlendirebilmektedir (Anderman ve Midgley, 2004; Papanastasiou ve Zembylas, 2006; Sobel, 2009). Bu durum, özellikle söz konusu derslerin öğretmenlerinin, öğrencilerinin derslerine ilişkin mevcut inançlarıyla, kopya çekmeye yönelik tutumlarını dikkate almalarının önemli olduğuna işaret etmektedir. Ancak, kopya çekmeye yönelik olumlu tutumlara sahip bir matematik ya da fen bilgisi öğretmeninin, öğrencilerinin kopya çekmeye yönelik tutumlarına 
ve/veya öğrenme sürecini olumsuz yönde etkileyebilecek inançlarına odaklanma konusunda dikkate değer bir hassasiyete sahip olmasını beklemek gerçekçi değildir. Üstelik öğretmenlik mesleğine yönelik olumsuz tutumlara sahip bir öğretmen için bu hassasiyetin daha da az olacağı öne sürülebilir. Birlikte düşünüldüğünde, bu açıklamalar kopya çekmeye yönelik tutumlarla öğretmenlik mesleğine yönelik tutumlar arasındaki olası ilişkinin, fen bilgisi öğretmen adaylarını kapsayan bir örneklemden hareketle incelenmesinin yalnızca mantıklı olmadığı, aynı zamanda önemli olduğu anlamına gelmektedir. Nitekim daha önce ifade edildiği gibi, fen bilgisi öğretmen adayları kopya çekmeye yönelik olarak tamamen olumsuz tutumlara sahip değildirler (Er ve Gürgan, 2011).

Dolayısıyla, araştırmanın örneklemini 2012-2013 akademik yılı güz döneminde Türkiye'nin Batı Karadeniz bölgesinde yer alan bir üniversitenin Eğitim Fakültesi Fen Bilgisi Öğretmenliği bölümünde öğrenim gören, yaklaşık 600 öğretmen adayı arasından yansız atama yoluyla seçilen 250 öğretmen adayı oluşturmuştur. Örneklem büyüklüğünün araştırmada kullanılan ölçme araçlarından hareketle elde edilecek olan bulguları \% 95 güven aralığında ( $p<$ .05) yorumlamak için yeterli olduğu söylenebilir (Fraenkel vd., 2012).

Öğretmen adaylarının yaş ortalaması $20.13^{\prime}$ dür (SS= 1.71; Yaş aralığı = 17-32). Öğretmen adaylarının cinsiyet ve sınıf düzeylerine göre dağııımlarına Tablo 1'de, yaş ve cinsiyet değişkenlerine göre dağılımlarına ise Tablo 2' de yer verilmiştir.

Tablo 1: Öğrencilerin Sınıf Düzeyi ve Cinsiyet Değişkenlerine Göre Dağılımları

\begin{tabular}{cccccc}
\hline & K & Cinsiyet & & & \\
\hline Sinif & & 56 & 7 & Toplam & E \\
& 1 & 51 & 11 & 63 & 25 \\
& 2 & 54 & 15 & 69 & 25 \\
& 3 & 39 & 17 & 56 & 28 \\
Toplam & 4 & $\mathbf{2 0 0}$ & $\mathbf{5 0}$ & $\mathbf{2 5 0}$ & $\mathbf{1 0 0}$ \\
\hline
\end{tabular}

Tablo 2: Örneklemde Yer Alan Öğrencilerin Yaşa Göre Dağılımları

\begin{tabular}{ccccccc}
\hline & & \multicolumn{2}{c}{ Cinsiyet } & & & \\
& & K & E & Toplam & \% \\
\hline Yaş & 18 ve altı & 38 & 5 & 43 & 17 \\
& 19 & 37 & 7 & 44 & 18 \\
& 20 & 65 & 7 & 72 & 29 \\
& 21 & 34 & 14 & 48 & 19 \\
Toplam & 22 ve üstü & 26 & 17 & 43 & 17 \\
& & $\mathbf{2 0 0}$ & $\mathbf{5 0}$ & $\mathbf{2 5 0}$ & $\mathbf{1 0 0}$ \\
\hline
\end{tabular}


Tablo 1'de görüldüğü gibi, örneklemi oluşturan öğrencilerin büyük çoğunluğu kız öğretmen adaylarından ( $n=200$ ) oluşmaktadır. Kız öğretmen adaylarının büyük çoğunluğunun yaşları 20 yaş civarında yer alırken, erkek öğretmen adaylarının büyük çoğunluğunun $(n=31)$ yaşları 21 ve üstündedir. Öğretmen adaylarının sınıf düzeylerine göre dağılımları ise birbirlerine oldukça yakın değerlere sahip sayılarla temsil edilmektedir (bkz. Tablo 1). Söz konusu dağılımlar, örneklemin elde edildiği evrenle oldukça benzerdir. Dolayısıyla, örneklemin yaş, cinsiyet ve sınıf düzeyi değişkenleri bağlamında evreni temsil düzeyinin yüksek olduğu söylenebilir.

\subsection{Veri Toplama Araçları}

Araştırmada "Kopya Çekmeye Yönelik Tutum Ölçeği" (Yangın ve Kahyaoğlu, 2009) ve “Öğretmenlik Mesleğine Yönelik Tutum Ölçeği” (Üstüner, 2006) veri toplama araçları olarak kullanılmıştır. Kopya çekmeye yönelik tutum ölçeği tek faktörlü ve toplam 30 maddeden oluşan bir ölçektir (Örnek madde: Kendisine saygısı olan insan kopya çekmez.). Öğretmenlik mesleğine yönelik tutum ölçeği ise tek faktörlü ve toplam 34 maddeden oluşan bir ölçme aracıdır (Örnek madde: Öğretmen olma düşüncesi bile bana cazip geliyor.). Her iki ölçme aracı da 1'den (kesinlikle katılmıyorum) 5'e (tamamen katılıyorum) uzanan cevap seçeneklerine sahip beşliLikert tipi yanıt formatına sahiptir. Ölçme araçlarının faktör yapılarının bu araştırmanın örnekleminde doğrulanıp doğrulanmadığının incelenmesi amacıyla, iki ayrı doğrulayııı faktör analizi (DFA) gerçekleştirilmiştir. DFA, AMOS 16 (Arbuckle, 2007) programı aracılığıyla ve en yüksek olabilirlik yöntemi (Maximum Likelihood) kullanılarak gerçekleştirilmiştir. Faktöriyel yapının gözlemlenen değerlerle uyum derecesinin belirlenebilmesi amacıyla Normlaştırılmış Uyum İndeksi (NFI $\geq .90$ ), Normlaştırılmamış Uyum İndeksi (NNFI $\geq 0.90$ ), Karşılaştırmalı Uyum İndeksi (CFI $\geq .90)$ ve Standartlaştırılmış Artık Ortalamaların Karekökü (SRMR $\leq .08$ ) hesaplanmıştır (Çokluk, Şekercioğlu ve Büyüköztürk, 2012; Kline, 2011). Ki-kare $\left(\chi^{2}\right)$ değeri örneklem büyüklüğüne hassas bir ölçü olması nedeniyle, bir uyum indeksi olarak alınmamış, ancak betimsel amaçla rapor edilmiştir.

DFA sonucunda tek faktörlü ve 30 maddeli modelin (kopya çekmeye yönelik tutum ölçeği) bu araştırma kapsamında elde edilen verilerle iyi bir uyum gösterdiği saptanmıştır $\left(\chi^{2}(405)=1494.52 ; \mathrm{NFI}=.93 ; \mathrm{NNFI}=.95 ; \mathrm{CFI}=.95 ; \mathrm{SRMR}=.07\right)$. Benzer biçimde, tek faktörlü ve 34 maddeden oluşan modelin de (öğretmenlik mesleğine yönelik tutum ölçeği) araştırmanın verileriyle iyi bir uyum gösterdiği belirlenmiştir $\left(\chi^{2}(527)=1909.39 ; \mathrm{NFI}=.92 ; \mathrm{NNFI}=.94 ; \mathrm{CFI}=\right.$ $.94 ;$ SRMR = .07). Kopya çekmeye yönelik tutum ölçeği ile öğretmenlik mesleğine yönelik tutum 
ölçeğine ilişkin Cronbach alfa katsayıları ise sırasıyla, .93 ve .95 olarak hesaplanmıştır. Bu bulgular, söz konusu ölçme araçlarının yapı geçerlikleriyle iç tutarlılık güvenirliklerinin, bu araştırmanın örneklemi kapsamında tatmin edici olduğunu göstermiştir.

\section{3. İşlem yolu}

Kopya Çekmeye Yönelik Tutum Ölçeği ve Öğretmenlik Mesleğine Yönelik Tutum Ölçeği araştırmacı tarafından, ders saatleri içerisinde ve öğretim elemanlarının uygun gördükleri bir zaman diliminde uygulanmıştır. Ölçme araçları öğrencilere araştırmanın amacının açıkça belirtildiği birer yönergeyle dağıtılmış, uygulama başlamadan önce araştırmanın amacı öğrencilere yüksek sesle okunmuş ve araştırmaya katılımın gönüllülük esasına dayalı olduğu belirtilmiştir. Araştırma süresince öğrencilerden gelen sorular yanıtlanmıştır. Uygulama yaklaşık 20 dakika sürmüştür.

\subsection{Verilerin Çözümlenmesi}

Kopya Çekmeye Yönelik Tutum Ölçeği ve Öğretmenlik Mesleğine Yönelik Tutum Ölçeğinden elde edilen veriler bilgisayar ortamına aktarılmış ve tüm analizler SPSS programı kullanılarak gerçekleştirilmiştir. Araştırmada öğretmenlik mesleğine yönelik tutum ve kopya çekmeye yönelik tutum değişkenlerine ilişkin olarak elde edilen verilerin normal dağılım koşulunu sağlaması ve örneklem büyüklüğünün yeterli olması nedeniyle veri analizinde parametrik testler kullanılmıştır (Field, 2009). Spesifik olarak, araştırmanın birinci sorusunun yanıtlanması amacıyla bağımsız gruplar için t testleri ve tek yönlü varyans analizleri, ikinci sorusunun yanıtlanması amacıyla sıfır-sıra korelasyon analizi ve üçüncü sorusunun yanıtlanması amacıyla da hiyerarşik küme analizleri gerçekleştirilmiştir. Hiyerarşik küme analizinde Ward yöntemi kullanılmış ve kümeleri oluşturan çiftler arasındaki Öklid uzaklık ölçülerinin kareleri dikkate alınmıştır (Rencher, 2002). Ayrıca, yorum kolaylığı sağlanması amacıyla, maddelerin toplanmasıyla elde edilen faktör puanları (kopya çekmeye yönelik tutum ve öğretmenlik mesleğine yönelik tutum) standartlaştırılmış ve küme analizleri standartlaştırılmış katsayılar (z katsayıları) üzerinden gerçekleştirilmiştir. Küme analizlerinin uç değerlere hassas olması nedeniyle, veri setindeki uç değerlerin saptanması amacıyla frekans analizi gerçekleştirilmiş ve üç öğretmen adayının yanıtlarının uç değerlere sahip oluğu belirlenmiştir ( $\pm 3 \mathrm{SS}$ ). Dolayısıyla, küme analizleri toplam 247 kişiden hareketle gerçekleştirilmiştir. 


\section{BULGULAR}

\subsection{Araştırmanın birinci sorusuna ilişkin analiz sonuçları}

Bağımsız gruplar için t testi sonuçları, öğretmen adaylarının kopya çekmeye yönelik tutumlarının cinsiyete göre anlamlı düzeyde farklılaştığını göstermiştir $(t(245)=2.48, p<.05$, Cohen's $d=.39$ ). Spesifik olarak, kız öğretmen adaylarının kopya çekmeye yönelik tutumları $(\bar{X}=84.82)$, erkek öğretmen adaylarına $(\bar{X}=94.18)$ göre anlamlı düzeyde daha olumsuzdur. Buna göre, kız öğretmen adaylarının kopya çekmeyi erkek öğretmen adaylarına göre daha olumsuz bir davranış olarak algıladıkları söylenebilir. Ortalamalar arasındaki farklılık anlamlı olmasına rağmen, hesaplanan etki büyüklüğünün $(d=.39)$ görece küçük olması ( $d<.50$, Cohen, 1988; Cohen, 1992), kız öğretmen adaylarının söz konusu algılamalarının erkek öğretmen adaylarından önemli düzeyde farklılaşmadığının bir göstergesi olarak yorumlanabilir.

Diğer taraftan, varyans analizi aracılığıyla elde edilen sonuçlar, öğretmen adaylarının kopya çekmeye yönelik tutumlarının sınıf düzeylerine göre anlamlı düzeyde farklılaşmadığını göstermiştir $\left(F(3,243)=.069, p=.976, \eta_{p}^{2}=.01\right)$. Üstelik sınıf düzeyi değişkeninin, öğretmen adaylarının kopya çekmeye yönelik tutumları üzerindeki etkisi de son derece zayıf bir etkidir $\left(\eta_{p}^{2}<.09\right.$, Cohen, 1988). Dolayısıyla, sınıf düzeyi değişkeninin kopya çekmeye yönelik tutum değişkeni üzerindeki etkisi ne anlamlı ne de önemlidir. Nitekim öğretmen adaylarının kopya çekmeye yönelik tutumlarının sınıf düzeylerine göre hesaplanan ortalamaları birbirlerine oldukça yakın değerlere sahiptirler (bkz. Tablo 3).

Tablo 3: Kopya Çekmeye Yönelik Tutum Puanlarının Betimsel İstatistikleri

\begin{tabular}{cccc}
\hline Sınıf Düzeyi & N & $\overline{\boldsymbol{X}}$ & SS \\
\hline 1 & 62 & 95.10 & 24.93 \\
2 & 61 & 96.65 & 19.26 \\
3 & 68 & 94.13 & 27.30 \\
4 & 56 & 95.38 & 24.70 \\
\hline
\end{tabular}

Öğretmen adaylarının öğretmenlik mesleğine ilişkin tutumları incelendiğinde de, kopya çekmeye yönelik tutumları için söz konusu olduğu gibi, cinsiyete göre anlamlı düzeyde farklılaştığı saptanmıştır $(t(245)=4.03, p<.05, d=.64)$. Buna göre, kız öğretmen adaylarının öğretmenlik mesleğine yönelik tutumları $(\bar{X}=134.63)$, erkek öğretmen adaylarına $(\bar{X}=121.14)$ göre anlamlı düzeyde daha olumludur. Üstelik ortalamalar arasındaki farkın anlamlılı̆ı dikkate değer bir etki büyüklüğüyle temsil edilmektedir (Cohen, 1992). Dolayısıyla, ortalamalar 
arasında saptanan bu farklılığın yalnızca anlamlı olmadığı, aynı zamanda önemli olduğu ifade edilebilir.

Diğer taraftan, varyans analizi sonuçları, öğretmen adaylarının öğretmenlik mesleğine yönelik tutumlarının sınıf düzeylerine göre anlamlı düzeyde farklılaşmadığını göstermiştir $\left(F(3,243)=2.51, p=.06, \eta_{p}^{2}=.03\right)$. Bu noktada, $p$ değerinden hareketle $(p=.06)$ marjinal bir anlamlılık düzeyinden söz edilebilmesine rağmen, etki büyüklüğünün oldukça küçük olması $\left(\eta^{2} p\right.$ $=$.03), marjinal değeri anlamsız hale getirmektedir. Bu nedenle, sınıf düzeyi değişkeninin öğretmenlik mesleğine yönelik tutum değişkeni üzerindeki etkisinin anlamlı ve önemli olmadığı söylenebilir. Nitekim öğretmen adaylarının kopya çekmeye yönelik tutumlarına ilişkin olarak hesaplanan ortalamalarla benzer biçimde, öğretmenlik mesleğine yönelik tutumlarının sınıf düzeylerine göre hesaplanan ortalamaları da birbirlerine oldukça yakın değerlere sahiptir (bkz. Tablo 4).

Tablo 4: Öğretmenlik Mesleğine Yönelik Tutum Puanlarının Betimsel İstatistikleri

\begin{tabular}{cccc}
\hline Sinıf Düzeyi & N & $\overline{\boldsymbol{X}}$ & SS \\
\hline 1 & 62 & 132.175 & 2.73 \\
2 & 61 & 131.371 & 2.74 \\
3 & 68 & 136.841 & 2.69 \\
4 & 56 & 126.232 & 2.75 \\
\hline
\end{tabular}

\subsection{Araştırmanın ikinci sorusuna ilişkin analiz sonuçları}

Korelasyon analizi sonucunda, öğretmen adaylarının kopya çekmeye yönelik tutumları ile öğretmenlik mesleğine yönelik tutumları arasında görece zayıf $(r<.30)$, ancak anlamlı ve negatif yönlü bir ilişki saptanmıştır $(r=-.21, p<.01)$. Bunun anlamı, öğretmen adaylarının öğretmenlik mesleğini benimseme eğilimlerinin kopya çekme davranışlarını benimseme eğilimleriyle aynı yönde olmadığıdır. Nitekim bu bağlamda hesaplanan determinasyon katsayısı $\left(r^{2}=.044\right)$, iki değişkeninin birbirlerine göre açıkladıkları varyans miktarının (\% $4.4 \approx \% 5$ ) dikkate değer olduğunu göstermektedir. Bu bulgular ışığında, öğretmen adaylarının öğretmenlik mesleğine yönelik olumlu tutumlara sahip olmalarının, kopya çekmeye yönelik olumsuz tutumlara sahip olmalarını ya da kopya çekmeye yönelik olumlu tutumlara sahip olmalarının, öğretmenlik mesleğine yönelik olumsuz tutumlara sahip olmalarını kısmen de olsa (\% 4.4) açıkladığı söylenebilir. 


\subsection{Araştırmanın üçüncü sorusuna ilişkin analiz sonuçları}

Öğretmenlik mesleğine yönelik tutum ve kopya çekmeye yönelik tutum değişkenleri arasında gözlemlenen anlamlı ilişki $(r=-.21, p<.01)$, bu iki değişkenin küme analizine birlikte dahil edilmesi gerektiği yönünde bir bulgu olarak değerlendirilebilir (Rencher, 2002). Bu nedenle, bu iki değişken küme analizine birlikte dahil edilmiştir. Küme analizi sonucunda dallanma grafiği iki kümeli çözümlemenin, diğer küme çözümlemelerine göre daha mantıklı olduğunu göstermiştir. Dolayısıyla, küme analizi iki kümeli çözümleme seçeneğiyle yeniden gerçekleştirilmiştir. Analiz sonucunda elde edilen küme merkezlerine Tablo 5'te yer verilmiştir.

Tablo 5: Küme Merkezleri

\begin{tabular}{cccc}
\hline & & ÖMT & KYT \\
Küme No & $\mathrm{n}(\%)$ & $\mathrm{z}(\mathrm{SS})$ & $\mathrm{z}(\mathrm{SS})$ \\
\hline 1 & $144(58.3)$ & $-.07(.99)$ & $.66(.61)$ \\
2 & $103(41.7)$ & $.18(.86)$ & $-.96(.53)$ \\
\hline
\end{tabular}

Not: ÖMT = öğretmenlik mesleğine yönelik tutum; KYT = kopya çekmeye yönelik tutum

Küme analizi sonucunda ortaya çıkan iki örüntünün ayırt edici olup olmadığı ise, tek yönlü varyans analizi aracılığıyla incelenmiştir. Analiz sonuçları, hem öğretmenlik mesleğine yönelik tutum $(F(1,245)=4.46, p<.05)$ hem de kopya çekmeye yönelik tutum $(F(1,245)=$ 474.46, $\mathrm{p}<.001)$ değişkenlerinin birinci ve ikinci kümeler açısından birbirlerine göre anlamlı düzeyde farklılaştığını göstermiştir. Bunun anlamı, kümelerin söz konusu değişkenler açısından ayırt edici özelliklere sahip olduklarıdır. Dolayısıyla, küme merkezlerinden hareketle (bkz. Tablo 5), birinci ve ikinci kümeler sırasıyla 'öğretmenliğe karşı olumsuz kopya çekmeye karşı olumlu tutuma sahip olanlar kümesi' ve 'öğretmenliğe karşı olumlu, kopya çekmeye karşı olumsuz tutuma sahip olanlar kümesi' olarak adlandırımıştır.

\section{TARTIŞMA VE SONUÇ}

Araştırmanın bulguları, fen bilgisi öğretmen adaylarının kopya çekmeye yönelik tutumlarının cinsiyete göre anlamlı düzeyde farklılaştığını göstermiştir. Spesifik olarak, kız öğretmen adayları erkek öğretmen adaylarına göre kopya çekmeye karşı daha olumsuz tutumlara sahiptirler. Bu sonuç, erkek öğretmen adaylarının kız öğretmen adaylarına göre kopya çekmeyi görece daha olumlu bir davranış biçimi olarak algıladıkları şeklinde yorumlanabilir. Bu bulgu, bundan önce gerçekleştirilen araştırmalardan elde edilen bulgularla benzerlik göstermektedir (Akdağ ve Güneş, 2002; Er ve Gürgan, 2011; Semerci, 2004; Whitley vd., 1999; Yangın ve Kahyaoğlu, 2009). Elde edilen bu bulgu, kız öğrencilerin ders çalışma 
düzeylerinin erkek öğrencilere kıyasla daha fazla olması (Aral ve Aktaş, 1997) ve bu nedenle kopya çekmeye intiyaç duymamaları olgusuna dayalı olarak yorumlanabilir. Alternatif olarak, dünya geneli için geçerli olduğu gibi, Türkiye'de de öğretmenlik mesleğinin bir kadın mesleği olarak algılanması, kız öğretmen adaylarının öğretmenlik mesleğini daha fazla benimsemelerine ve bu nedenle de kopya çekme davranışlarını daha olumsuz bir bakış açısıyla değerlendirmelerine yol açabilir. Nitekim bu yorumu destekler nitelikte, araştırmanın bulguları kız öğretmen adaylarının öğretmenlik mesleğine yönelik tutumlarının, erkek öğretmen adaylarına göre anlamlı düzeyde daha olumlu olduğunu göstermiştir (benzer bulgular için bkz. Özbek vd., 2007; Pektaş ve Kamer, 2011; Terzi ve Tezci, 2007).

Cinsiyet değişkenine yönelik olarak bu araştırmada elde edilen bulgular birlikte ele alındığında, öğretmen eğitimi açısından önemli bir noktaya dikkat çekmektedir. Bu nokta, öğretmenlik mesleğinin kız ve erkek öğrenciler tarafından nasıl algılandığının, kopya çekme ve mesleğe yönelik tutum gibi iki önemli değişken açısından önemli sonuçları olabileceğidir. Bu nedenle, öğretmen eğitimcileri öğrencilerini mesleğin gerektirdiği niteliklerin kız ya da erkek olmaya göre değil, mesleğe adanmışlık, kişisel sorumluluk alma ve kendini geliştirme arzusu gibi özelliklere göre biçimlendiği konusunda bilgilendirmelidirler (Day, Elliot ve Kington, 2005).

Diğer taraftan, araştırmanın bulguları öğretmen adaylarının kopya çekmeye yönelik tutumları ile öğretmenlik mesleğine yönelik tutumlarının öğrenim gördükleri sınıf düzeylerine göre farklılaşmadığını göstermiştir. Konuyla ilgili literatürde, öğretmen adaylarının kopya çekmeye yönelik tutumlarının sınıf düzeylerine göre farklıık gösterdiğinin rapor edildiği araştırmalarla birlikte (Er ve Gürgan, 2011; Semerci, 2004), sınıf düzeyine bağlı olarak anlamlı farklııkların rapor edilmediği çalışmalar da bulunmaktadır (Akdağ ve Güneş, 2002). Benzer biçimde, çelişkili bulgular öğretmen adaylarının öğretmenlik mesleğine yönelik tutumlarının sınıf düzeylerine göre incelendiği araştırmalar için de söz konusudur (Terzi ve Tezci, 2007; Pektaş ve Kamer, 2011; Tanel vd., 2007). Sınıf düzeyi değişkenine yönelik olarak belirginleşen çelişkili bulgular, bu araştırmaların örneklemlerine ilişkin büyüklük ve içerik farklılıklarından kaynaklanabilir. Üstelik bu araştırmalarda etki büyüklüklerinin rapor edilmemiş olması, bundan önce gerçekleştirilen araştırmalardan elde edilen bulgularla, bu araştırmanın sınıf düzeyine yönelik olarak elde edilen bulgularının karşılaştırımasını güçleştirmektedir. Ancak, bu araştırmada sınıf düzeyi değişkeninin öğretmenlik mesleğine yönelik tutum ve kopya çekmeye yönelik tutum değişkenleri üzerindeki etki büyüklüklerinin oldukça küçük değerlere sahip olması, sınıf düzeyi değişkeninin etkilerinin önemli olmadığının sağlam bir göstergesi olarak 
yorumlanabilir. Bu nedenle, öğretmen eğitimcileri öğrencilerinin kopya çekmeye yönelik tutumlarında ve öğretmenlik mesleğine yönelik tutumlarında arzu edilen değişimin sağlanmasının, öğretmen eğitiminde geçen zamanın değil, bu yönde kullanılabilecek etkili yöntemlerin (örneğin tutumlara ilişkin farkındalık yaratma ve nedenlerin tartışıması vb.) bir fonksiyonu olabileceği ihtimalini dikkate almalıdırlar.

Önemli olarak, bu araştırmada öğretmen adaylarının öğretmenlik mesleğine yönelik tutumları ile kopya çekmeye yönelik tutumları arasında görece zayıf, ancak anlamlı ve negatif yönlü bir ilişki saptanmıştır. Öğretmenlik mesleğinin dürüstlük ve çaba kavramlarını merkezine alan bir meslek olduğu düşünüldüğünde, bu mesleğin adaylarının, en azından aldıkları eğitimin bir sonucu olarak kopya çekmeye yönelik tutumlarıyla mesleğe yönelik tutumları arasında negatif yönlü bir ilişki bekleneceği söylenebilir. Dolayısıyla, söz konusu değişkenler arasındaki ilişkiye yönelik olarak elde edilen korelasyon katsayısının görece zayıf olması düşündürücüdür. Bunun bir olası nedeni, öğretmen adaylarının öğretmen kimliklerinin henüz tam anlamıyla gelişmemiş olması nedeniyle, kopya çekmeye yönelik davranışları halen öğrenci bakış açısıyla değerlendirmeleri olabilir. Ancak bu çalışmada öğretmen kimliğinin incelenmemiş olması, bu yorumu mantıklı olmasına rağmen, tartışmalı hale getirmektedir. Dolayısıyla, söz konusu yorumun gelecekte yapılacak araştırmaları gerektirdiği açıktır.

Daha önemlisi, bu araştırmada kişi merkezli analiz (küme analizi) aracılığıyla elde edilen bulgular, değişken merkezli analiz (korelasyon analizi) aracılığıyla elde edilen bulguyla paralel biçimde, öğretmen adaylarının kopya çekmeye yönelik tutumlarıyla öğretmenlik mesleğine yönelik tutumlarının iki anlamlı küme örüntüsü aracılığıyla açıklanabildiğini göstermiştir. Spesifik olarak, bu kümeler 'öğretmenliğe karşı olumsuz kopya çekmeye karşı olumlu tutuma sahip olanlar kümesi' ve 'öğretmenliğe karşı olumlu, kopya çekmeye karşı olumsuz tutuma sahip olanlar kümesi' olarak adlandırımıştır. Bu bağlamda elde edilen ilk bulgu olması, bu bulgunun bundan önce gerçekleştirilen araştırmalara atıfla yorumlanmasını güçleştirmektedir. Ancak, daha önce ifade edildiği gibi, öğretmenlik mesleğinin çaba ve dürüstlük gibi ilkeleri içeren bir meslek olduğu dikkate alındığında, öğretmenlik mesleğine yönelik olumlu tutumla kopya çekmeye yönelik olumlu tutumun aynı küme içerisinde ve aynı düzeyde yer almaması beklenebilir.

Diğer taraftan, öğretmenliğe karşı olumsuz, kopya çekmeye karşı olumlu tutuma sahip olanlar kümesinin kapsadığı öğretmen adayı sayısının, öğretmenliğe karşı olumlu, kopya çekmeye karşı olumsuz tutuma sahip olanlar kümesinin kapsadığı öğretmen adayı sayısından 
dikkate değer biçimde yüksek olması düşündürücüdür. Bu durumun bir olası nedeni, yukarıda da vurgulandığı gibi öğretmen adaylarının öğretmen kimliklerinin henüz tam anlamıyla gelişmemiş olmasının, kopya çekmeye yönelik davranışlarını öğrenci bakış açısıyla değerlendirmelerine yol açması olabilir. Bu noktada, öğretmen eğitimcilerinin öğrencilerine kopya çekmeye yönelik tutumlarının kaynaklarını sorgulama ve tartışma olanağı sağlamalarının ve/veya etkili öğrenme ve verimli ders çalışma stratejilerini öğrenmeleri konusunda yardımcı olmalarının, öğrencilerinin söz konusu tutumları üzerinde olumlu sonuçları olacağı ifade edilebilir (Franklyn-Stokes ve Newstead, 1995; Seven ve Engin, 2008).

Öğretmenliğe karşı olumsuz kopya çekmeye karşı olumlu tutuma sahip olanlar kümesinin kapsadığı öğretmen adayı sayısının, öğretmenliğe karşı olumlu, kopya çekmeye karşı olumsuz tutuma sahip olanlar kümesinin kapsadığı öğretmen adayı sayısından belirgin biçimde yüksek olması, Türkiye'de üniversiteye girişin yönlendirmeden çok, sıralamayı hedefleyen sınavlara bağı olması ve ortaöğretim kurumlarındaki mesleki danışmanlık ve rehberlik hizmetlerinin yeterli olmaması gibi nedenlere de bağıı olabilir (Arslan ve Kılıç, 2000; Çakar ve Kulaksızoğlu, 1997; Sönmez, 2008). Dolayısıyla, bu konulara ilişkin olarak yapılacak düzenlemelerin ve etkili hizmet sağlama girişimlerinin, öğretmenlik mesleğine yönelik tutumları olumlu yönde etkileme açısından son derece önemli sonuçları olacağı söylenebilir. Dünyanın hemen her ülkesinde, öğretmen eğitim programlarının genel amaçlarının nitelikli ve mesleğe adanmışlık düzeyi yüksek öğretmenler yetiştirmek olduğu dikkate alındığında (Nuland, 2011; O’Meara, 2011), söz konusu düzenleme ve girişimlerin içerdiği önem daha da belirginleşmektedir.

$\mathrm{Bu}$ araştırmadan elde edilen bulgular üç önemli sonuç ortaya koymuştur. Birincisi, öğretmen adaylarının kopya çekmeye yönelik tutumları ile öğretmenlik mesleğine ilişkin tutumlarının cinsiyetlerine göre farklılaştığıdır. İkincisi, öğretmen adaylarının kopya çekmeye yönelik tutumlarıyla öğretmenlik mesleğine yönelik tutumlarının anlamlı ve negatif yönlü ilişkilendiğidir. Sonuncusu ve daha önemlisi, öğretmen adaylarının kopya çekmeye yönelik tutumlarıyla öğretmenlik mesleğine yönelik tutumları arasında değişken düzeyinde gözlemlenen negatif yönlü ve anlamlı ilişkinin, kişi düzeyinde 'öğretmenliğe karşı olumsuz kopya çekmeye karşı olumlu tutuma sahip olanlar kümesi' ve 'öğretmenliğe karşı olumlu, kopya çekmeye karşı olumsuz tutuma sahip olanlar kümesi' olarak adlandırılabilecek iki küme örüntüsü aracılığıyla açıklanabildiğidir. 
Yukarıda detaylı biçimde değinildiği gibi, bu bulgular öğretmen eğitimi açısından önemli doğurgular içermesine rağmen, görece küçük bir örneklemden ve yalnızca fen bilgisi öğretmen adaylarından hareketle gerçekleştirilmiş olması, araştırmadan elde edilen bulguların genellenebilirliğini sınırlamaktadır. Dolayısıyla, gelecekte daha büyük örneklemlerden ( $\mathrm{n}$ > 1000) ve farklı öğretmen eğitim programlarında öğrenim gören öğretmen adaylarından hareketle yapılacak olan araştırmalar, bu konuya ilişkin daha kapsamlı bir bakış açısı geliştirilmesine ve daha güvenilir sonuçların ortaya konmasını sağlayabilir.

Araştırmanın deseninin ilişkisel bir desen olması, değişkenler arasında saptanan ilişkinin nedenselliği konusunda bir bilgi vermemektedir. Gelecekte deneysel desenlerden hareketle yapılacak olan araştırmalar, öğretmen adaylarının öğretmenlik mesleğine yönelik tutumlarının mı kopya çekmeye yönelik tutumlarını etkilediğini, yoksa kopya çekmeye yönelik tutumlarının mı öğretmenlik mesleğine yönelik tutumlarını etkilediği konusunda sağlam bulgular ortaya koyma potansiyeline sahiptir.

Son olarak, bu araştırmada öğretmen adaylarının kopya çekmeye yönelik tutumları ile öğretmenlik mesleğine yönelik tutumları arasındaki ilişkide rol oynayabilecek kariyer geliştirme arzuları ve mesleki yönelim gibi önemli değişkenlerin arabuluculuk rolleri incelenmemiştir (Eren, 2012; Eren ve Tezel, 2010; Watt ve Richardson, 2007, 2008). Oysa bu değişkenler, öğretmen adaylarının öğretmenlik mesleğine yönelik tutumlarıyla kopya çekmeye yönelik tutumları arasındaki ilişkinin çok daha kapsamlı bir bakış açısıyla yorumlanmasına olanak sağlayabilir.

\section{KAYNAKLAR}

Akdağ, M. ve Güneş, H. (2002). Kopya Çekme Davranışları ve Kopya Çekmeye Yönelik Tutumlar. Kuram ve Uygulamada Eğitim Yönetimi, 31, 330-343.

Akpınar, E., Yıldız, E. ve Ergin, Ö. (2006). Fen Bilgisi Öğretmen Adaylarının Öğretmenlik Mesleğine Yönelik Tutumları. Buca Eğitim Fakültesi Dergisi, 19, 56-62.

Anderman, E. M. ve Midgley, C. (2004). Changes in Self-Reported Academic Cheating across the Transition from Middle School to High School. Contemporary Educational Psychology, 29, 499-517.

Aral, N. ve Aktaş, Y. (1997). Çocukların Televizyon ve Diğer Etkinliklere Harcadıkları Sürenin İncelenmesi. Hacettepe Üniversitesi Eğitim Fakültesi Dergisi, 13, 99-105.

Arbuckle, J. L. (2007). AMOS 16.0 User's Guide. Spring House, PA: Amos Development Corporation.

Arslan, M. M. ve Kılıç, Ç. (2000). Bazı Avrupa Ülkelerinde ve Türkiye'de Zorunlu Eğitimde Yönlendirme Çalışmalarının Değerlendirilmesi. Milli Eğitim Dergisi, 148. 
Atılgan, H. (2005). Genellenebilirlik Kuramı ve Puanlayıcılar Arası Güvenirlik İçin Örnek Bir Uygulama. Eğitim Bilimleri ve Uygulama, 4(7), 95-108.

Aydın, R. ve Sağlam, G. (2012). Öğretmen Adaylarının Öğretmenlik Mesleğine Yönelik Tutumlarının Belirlenmesi (Mehmet Akif Ersoy Üniversitesi Örneği). Türk Eğitim Bilimleri Dergisi, 10(2), 257-294.

Aydoğan, ì. (2008). Küreselleşme ve Etkisi: Rus ve Kırım Tatar Öğrencilerinin Tutum ve Davranışlarının Analizi. Erciyes Üniversitesi Sosyal Bilimler Enstitüsü Dergisi, 25(2), 107-118.

Bahar, M., Nartgün, Z., Durmuş, S. ve Bıçak, B. (2010). Ölçme ve Değerlendirme Teknikleri Öğretmen El Kitabı. Ankara: Pegem Akademi.

Bozdoğan, A. E. ve Öztürk, Ç. (2008). Öğretmen Adayları Neden Kopya Çeker?. ilköğretim Online, 7(1), 141-149.

Büyüköztürk, Ş. (2011). Sosyal Bilimler İçin Veri Analizi El Kitabı (11. Baskı). Ankara: Pegem.

Büyüköztürk, Ş., Kılıç Çakmak, E., Akgün, Ö. E., Karadeniz, ş. ve Demirel, F. (2011). Bilimsel Araştırma Yöntemleri (8. Baskı). Ankara: Pegem.

Cohen, J. (1988). Statistical Power Analysis for The Behavioral Sciences (2nd. Edition). Hillsdale, NJ: Erlbaum.

Cohen, J. (1992). A Power Primer. Psycological Bulletin, 112(1), 155-159.

Çakar, M. ve Kulaksızoğlu, A. (1997). Lise Son Sınıf Öğrencilerinin Mesleki Olgunluk Düzeyleri ile Denetim Odağı Düzeylerinin Karşılaştırılması. Marmara Üniversitesi Atatürk Eğitim Fakültesi Eğitim Bilimleri Dergisi, 9(9), 113-131.

Çelikten, M., Şanal, M. ve Yeni, Y. (2005). Öğretmenlik Mesleği ve Özellikleri. Erciyes Üniversitesi Sosyal Bilimler Enstitüsü Dergisi, 19(2), 207-237.

Çetin, Ş. (2007). Üniversite Öğrencilerinin Kopya Çekme Davranışlarının Farklı Değişkenler Açısından İncelenmesi. Milli Eğitim, 175, 129-142.

Çokluk, Ö., Şekercioğlu, G. ve Büyüköztürk, Ş. (2012). Sosyal Bilimler lçin Çok Değişkenli istatistik SPSS ve LISREL Uygulamaları (2. baskı). Ankara: Pegem.

Day, C., Elliot, B. ve Kington, A. (2005). Reform, Standards and Teacher Identity: Challenges of Sustaining Commitment. Teaching and Teacher Education, 21, 563-577.

Durmuşçelebi, M. (2011). Lise Öğrencilerinin ve Öğretmen Adaylarının Kopya Çekme Davranışlarına Iliş̧in Görüşleri. Kuram ve Uygulamada Eğitim Yönetimi [Educational Administration: Theory and Practice], 17(1), 77-97.

Enker, M. S. (1987). Attitudinal and Normative Variables as Predictors of Cheating Behavior. Journal of Cross-cultural Psychology, 18(3), 315-330.

Er, K. O. ve Gürgan, U. (2011). Öğretmen Adaylarının Öz-Yeterlilik Algıları ve Kopya Çekmeye İlişkin Tutumları Arasındaki İlişki. Balıkesir Üniversitesi Sosyal Bilimler Enstitüsü Dergisi, 14(26), 1-18.

Erarslan, A. (2011). Matematik Öğretmeni Adayları ve Kopya: Hiç Çekmedim Desem Yalan Olur! Eğitim ve Bilim, 36(160), 52-64.

Eren, A. (2012). Öğretmen Adaylarının Mesleki Yönelimi, Kariyer Geliştirme Arzuları ve Kariyer Seçim Memnuniyeti. Kastamonu Eğitim Dergisi, 20(3), 807-826. 
Eren, A. ve Tezel, K. V. (2010). Factors Influencing Teaching Choice, Professional Plans About Teaching, and Future Time Perspective: A Mediational Analysis. Teaching and Teacher Education, 26, 1416-1428.

Field, A. (2009). Discovering Statistics Using SPSS. London: Sage.

Fraenkel, J. R., Wallen, N. E. ve Hyun, H. H. (2012). How to Design and Evaluate Research in Education (8. Edition). United States: Mc Graw Hill.

Franklyn-Stokes, A. ve Newstead, S. E. (1995). Undergraduate Cheating: Who Does What and Why?. Studies in Higher Education, 20(2), 159-172.

Freeman L. C. ve Ataöv, T. (1960). Invalidity of Indirect and Direct Measures of Attitude toward Cheating. Journal of Personality, 28, 443-447.

Fryer, J. W. ve Elliot, A. J. (2007). Stability and Change in Achievement Goals. Journal of Educational Psychology, 99(4), 700-714.

Hacıömeroğlu, G. ve Şahin Taşkın, Ç. (2010). Fen Bilgisi Öğretmenliği ve Ortaöğretim Fen ve Matematik Alanları (OFMA) Eğitimi Bölümü Öğretmen Adaylarının Öğretmenlik Mesleğine iliş̧kin Tutumları. Ahi Evran Üniversitesi Eğitim Fakültesi Dergisi, 11(1), 7790.

Hiebert, J., Gallimore, R. ve Stigler, J. W. (2002). A Knowledge Base for the Teaching Profession: What Would It Look Like and How Can We Get One?. Educational Researcher, 31(5), 3-15.

Kimberlin, C. L. ve Winterstein, A. G. (2008). Validity and Reliability of Measurement Instruments Used in Research. American Journal of Health-System Pharmacy, 65, 22762284.

Kline, R. B. (2011). Principles and Practice of Structural Equation Modeling (3rd. Edition). New York, NY: Guilford.

Lawson, R. A. (2004). Is Classroom Cheating Related to Business Students' Propensity to Cheat in The "Real World"?. Journal of Business Ethics, 49, 189-199.

Lüle Mert, E. (2012). Temel İşlevi Bilim İnsanı Yetiştirmek Olan Bazı Bölümlerde Kopya. Turkish Studies International Periodical For The Languages, Literature and History of Turkish or Turkic, 7(3), 1813-1829.

McCabe, D. L., Treviño, L. K. ve Butterfield, K. D. (2001). Cheating in Academic Institutions: A Decade of Research. Ethics \& Behavior, 11(3), 219-232.

Miller, A., Shoptaugh, C. ve Wooldridge, J. (2011). Reasons Not to Cheat, Academic-integrity Responsibility, and Frequency of Cheating. The Journal of Experimental Education, 79(2), 169-184.

Nuland, S. V. (2011). Teacher Education in Canada. Journal of Education for Teaching, 37(4), 409-421.

O'Meara, J. (2011). Australian Teacher Education Reforms: Reinforcing The Problem or Providing a Solution? Journal of Education for Teaching, 37(4), 423-431.

Papanastasiou, E. C. ve Zembylas, M. (2006). Did the Cypriot Students Really Cheat on TIMSS? Research in Comparative \& International Education, 1(2), 120-125. 
Özbek, R., Kahyaoğlu, M. ve Özgen, N. (2007). Öğretmen Adaylarının Öğretmenlik Mesleğine Yönelik Görüşlerinin Değerlendirilmesi. Sosyal Bilimler Dergisi, 9(2), 221-232.

Pektaş, M. ve Kamer, S. T. (2011). Fen Bilgisi Öğretmen Adaylarının Öğretmenlik Mesleğine Yönelik Tutumları. Türk Eğitim Bilimleri Dergisi, 9(4), 829-850.

Rencher, A. C. (2002). Methods of multivariate analysis. New York, NY: Wiley.

Richardson, J. T. E. (2011). Eta Squared and Partial Eta Squared as Measures of Effect Size in Educational Research. Educational Research Review, 6(2), 135-147.

Richardson, P. W. ve Watt, H. M. G. (2006). Who Chooses Teaching and Why? Profiling Characteristics And Motivations Across Three Australian Universities. Asia-Pacific Journal of Teacher Education, 34(1), 27-56.

Seferoğlu, S. S. (2004). Öğretmen Yeterlikleri ve Mesleki Gelişim. Bilim ve Aklın Aydınlığında Eğitim, 58, 40-45.

Semerci, Ç. (2004). Tıp Fakültesi Öğrencilerinin Kopya Çekmeye Yönelik Tutum ve Görüşleri. Fırat Üniversitesi Sağlık Bilimleri Dergisi, 18(3), 139-146.

Semerci, Ç. ve Sağlam Z. (2005). Polis Adaylarının Sınavlarda Kopya Çekmeye İlişkin Tutum ve Görüşleri (Elazığ ili Örneği). Fırat Üniversitesi Sosyal Bilimler Dergisi, 15(2), 163-177.

Seven, M. A. ve Engin, A. O. (2008). Eğitim Fakültesi Öğrencilerinin Kopya Çekmeye Duydukları ìtiyaç ve Kopya Çekme Sebepleri. Atatürk Üniversitesi Sosyal Bilimler Enstitüsü Dergisi, 11(1), 121-136.

Sherrill, D., Salisbury, J. L., Horowitz, B. ve Friedman, S. T. (1971). Classroom Cheating: Consistent Attitude, Perception, and Behavior. American Educational Research Journal, 8(3), 503-510.

Sobel, M. (2009). Physics for the Non-Scientist: A Middle Way. Physics Teacher, 47, 346-349.

Sönmez, M. (2008). Türkiye'de Mesleki ve Teknik Örgün Öğretimin Sorunları ve Yeniden Yapılandırılma Zorunluluğu. Eğitim ve Bilim, 33(147), 71-84.

Tan, S. (2002). Kopya Çekmeyi Önleme Tedbirleri. Ĕgitim ve Bilim, 122 (26), 32-40.

Tanel, R., Kaya Şengören, S. ve Tanel, Z. (2007). Fizik Öğretmen Adaylarının Öğretmenlik Mesleğine İlişkin Tutumlarının Farklı Değişkenler Açısından Incelenmesi. Pamukkale Üniversitesi Eğitim Fakültesi Dergisi, 22(2), 1-9.

Terzi, A. R. ve Tezci, E. (2007). Necatibey Eğitim Fakültesi Öğrencilerinin Öğretmenlik Mesleğine İlişkin Tutumları. Kuram ve Uygulamada Eğitim Yönetimi, 52, 593-614.

Topcu, Y. ve Uzundumlu, A. S. (2011). Yüksek Öğretimde Öğrencilerin Kopya Çekme Motivasyonu ile Iligili Tutum ve Davranışları. Uluslararası Insan Bilimleri Dergisi, $8(2), 302-313$.

Türk Dil Kurumu (2012). Sözlükler. http://www.tdk.gov.tr/index.php?option=com_ gts\&arama=gts\&guid=TDK.GTS.50f26bbd324116.70379748. (Erişim Tarihi: 29 Aralık 2012).

Üstüner, M. (2006). Öğretmenlik Mesleğine Yönelik Tutum Ölçeğinin Geçerlik ve Güvenirlik Çalışması. Kuram ve Uygulamada Eğitim Yönetimi, 45, 109-127. 
Walkington, J. (2005). Becoming a Teacher: Encouraging Development of Teacher Identity Through Reflective Practice. Asia-Pacific Journal of Teacher Education, 33(1), 53-64.

Watt, H. M. G., ve Richardson, P.W. (2007). Motivational Factors İnfluencing Teaching as a Career Choice: Development and Validation of The FIT-Choice Scale. Journal of Experimental Education, 75(3), 167-202.

Watt, H. M. G., ve Richardson, P.W. (2008). Motivations, Perceptions, and Aspirations Concerning Teaching as a Career for Different Types of Beginning Teachers. Learning and Instruction, 18(5), 408-428.

Whitley, B. E., Nelson, A. B. ve Jones, C. J. (1999). Gender Diferences in Cheating Attitudes and Classroom Cheating Behavior: A Meta-Analysis. Sex Roles, 41, 657-680.

Yangın, S. ve Kahyaoğlu, M. (2009). Illköğretim Öğretmen Adaylarının Kopya Çekmeye Yönelik Tutum ve Görüşleri. Balıkesir Üniversitesi Sosyal Bilimler Enstitüsü Dergisi, 12(21), 4655.

Yüksel, S. (2004). Tezsiz Yüksek Lisans Programının Öğrencilerin Öğretmenlik Mesleğine illişkin Tutumlarına Etkisi. Uludağ Üniversitesi Eğitim Fakültesi Dergisi, 17(2), 355-379. 


\section{SUMMARY}

The aim of this study is to examine the profiles of pre-service science teachers' attitudes towards the teaching profession and cheating. When the relevant literature about teacher candidates' attitudes towards the teaching profession and cheating is examined, it has not been found that a study examining the variables together. However, such an examination is important for at least one reason. The findings of the earlier studies on teacher candidates' attitudes towards cheating reveal that their attitudes are moderately positive. On the other hand, the findings of the earlier studies on teacher candidates' attitudes towards the teaching profession also reveal that they have positive attitudes regarding the teaching profession. These results signify a contradiction when one considers the fact that the teaching profession being formed of factors as honesty and effort in essence. Therefore, the findings of this study may significantly contribute to the solution of the mentioned contradiction.

This study is a descriptive study and the method of the study is survey method. Exploratory correlational design was adopted for the data analysis. The sample of the study contained 250 preservice science teachers who were randomly sampled among 600 pre-service teachers majoring in Science Teacher Education Program in the Faculty of Education at a university located in the north-west of the Black Sea region in Turkey. The Attitudes towards Cheating Scale and Attitudes towards Teaching Profession Scale were used as the data collection tools in the study. The factor structure of the instruments has been investigated through confirmatory factor analysis and internal consistencies of the scales were examined based on the Cronbach's coefficients alpha. With the aim of being examined the attitude of teachers towards teaching profession and cheating with a person-centered approach, correlation analysis was conducted together with hierarchical cluster analysis. Due to the finding a significant relationship between the total scores of the instruments, they were included cluster analysis together.

According to the findings of the study, female teacher candidates' attitudes are more negative than male teacher candidates' attitudes. This finding can be interpreted based on the fact that females study more than males and so they do not need to cheat. The perception of teaching as a female profession in Turkey may lead female teacher candidates to perceive the teaching profession as female profession more and therefore they may evaluate the attitudes of cheating with a more negative perspective. Indeed, this view is supported by the findings of the study that female teacher candidates' attitudes are significantly more positive than male teacher candidates' attitudes. This result may have important implications in terms of two important variables of cheating and teaching profession. On the other hand, the findings of the study also reveal that teacher candidates' attitudes towards cheating and teaching profession do not differ according to their grade levels. Furthermore, the effect size of grade level was small, indicating that the effect of grade level was negligible in the current sample. Therefore, it should be considered that obtaining desired changes in the attitudes of teacher candidates towards 
cheating and teaching profession cannot perceived as a function of duration of time in teacher education, but can be perceived as a function of using effective methods (for example, creating awareness related to attitudes and discussing reasons) during teacher education process. As the result of correlation analysis, it is found that negative and weak, but statistically significant relationship between the attitudes of candidate teachers towards teaching profession and cheating. Indeed, it is thought-provoking that correlation coefficient of the relationship between the variables is weak. The probable reason may be that the teacher candidates evaluate attitudes towards cheating in terms of 'student view' due to the fact that their teacher identities have not adequately developed yet.

More importantly, the results of cluster analysis show that these attitudes of teacher candidates can be described by two significant cluster patterns. Accordingly, the clusters are labeled as "negative attitudes towards the teaching profession and positive attitudes towards cheating cluster" and "positive attitudes towards the teaching profession and negative attitudes towards cheating cluster", respectively. When it is taken into consideration that teaching is a profession containing principles as effort and honesty, it can be expected that both positive attitudes towards teaching profession and negative attitudes towards cheating take part in the same cluster. Thus, it is interesting to observe that the number of teachers in the negative attitudes towards the teaching profession and positive attitudes towards cheating cluster are significantly more than the number of teachers in the positive attitudes towards the teaching profession and negative attitudes towards cheating cluster. At this point, it is worthwhile to say that this result may urge policy makers and teacher educators to focus on teacher candidates' attitudes towards cheating together with their attitudes towards the teaching profession in the early steps of their career ladders (i.e., teacher education). In fact, this result could be stemmed from the factors that in Turkey entering university is based on high-stake exams, and lack of effective vocational counseling and guidance services in secondary education institutions. Therefore, it can be said that regulations related to these and inferences for providing efficient services are highly important in order to affect the attitudes of teacher candidates towards teaching profession positively and effectively. Although the results of this study have significant potential to shed light on the relevant issues of teaching and teacher education (i.e., attitudes towards cheating and teaching profession), the results should cautiously be interpreted in future studies due to the small sample size, cross-sectional nature of the data, and obtaining the data from one university each of which considerably limits the generalizability of the current results. 